\title{
Op zoek naar informatiebronnen over de arbeidsmarktpositie van academici
}

Citation for published version (APA):

van Dam, J. W., de Grip, A., \& Heijke, J. A. M. (1988). Op zoek naar informatiebronnen over de arbeidsmarktpositie van academici. Researchcentrum voor Onderwijs en Arbeidsmarkt, Faculteit der Economische Wetenschappen. ROA Working Papers No. 3 https://doi.org/10.26481/umarow.1988003

Document status and date:

Published: 01/01/1988

DOI:

10.26481/umarow.1988003

Document Version:

Publisher's PDF, also known as Version of record

\section{Please check the document version of this publication:}

- A submitted manuscript is the version of the article upon submission and before peer-review. There can be important differences between the submitted version and the official published version of record.

People interested in the research are advised to contact the author for the final version of the publication, or visit the DOI to the publisher's website.

- The final author version and the galley proof are versions of the publication after peer review.

- The final published version features the final layout of the paper including the volume, issue and page numbers.

Link to publication

\footnotetext{
General rights rights.

- You may freely distribute the URL identifying the publication in the public portal. please follow below link for the End User Agreement:

www.umlib.nl/taverne-license

Take down policy

If you believe that this document breaches copyright please contact us at:

repository@maastrichtuniversity.nl

providing details and we will investigate your claim.
}

Copyright and moral rights for the publications made accessible in the public portal are retained by the authors and/or other copyright owners and it is a condition of accessing publications that users recognise and abide by the legal requirements associated with these

- Users may download and print one copy of any publication from the public portal for the purpose of private study or research.

- You may not further distribute the material or use it for any profit-making activity or commercial gain

If the publication is distributed under the terms of Article $25 \mathrm{fa}$ of the Dutch Copyright Act, indicated by the "Taverne" license above, 
OP ZOEK NAAR INFORMATIEBRONNEN OVER

DE ARBEIDSMARKTPOSITIE VAN ACADEMICI

ROA-W-1988/3

J.W. van Dam, A. de Grip, J.A.M. Heijke

RESEARCHCENTRUM VOOR ONDERWIJS EN ARBEIDSMARKT

Faculteit der Economische Wetenschappen

Rijksuniversiteit Limburg

Maastricht, november 1988 
1. INLEIDING 1

1.1. Gevolgde werkwijze 2

1.2. Opzet van dit werkdocument 2

2. NAAR EEN INFORMATIESYSTEEM ONDERWIJS - ARBEIDSMARKT 4

2.1. Uitgangspunten voor het informatiesysteem 4

2.2. Ontwikkelingsfasen van het informatiesysteem 4

2.3. Doeleinden van het informatiesysteem: de outputvariabelen 5

2.4. De benodigde gegevens voor het informatiesysteem 6

2.5. Te stellen eisen aan het datamateriaal 6

3. EEN INVENTARISATIE VAN ARBEIDSMARKTONDERZOEK ONDER ACADEMICI 9

3.1. Inleiding 9

3.2. Resultaten inventarisatie deelmarktonderzoeken 10

3.3. Conclusies 15

4. STICHTING MAATSCHAPPELIJKE PLAATS WAGENINGSE AFGESTUDEERDEN 18

5. GROOT-BRITTANNIE ALS VOORBEELD 24

5.1. Inleiding 24

5.1.1. De standaardvragenlijst 24

5.1.2. De aanvullende enquêtevragen 25

5.2. Problemen bij het onderzoek 26

5.3. Wat wordt er gedaan met de resultaten? 27

5.4. Conclusies 28

6. BESLUIT 29

BIJLAGE I : Overzicht van deelmarktstudies en databestanden 31

BIJLAGE II : Definities en classificaties MPW-onderzoek 45

BIJLAGE III: Definities en classificaties AGCAS (Groot-Brittannië) 48

BIJLAGE IV : Publicatie-overzicht van geĩnventariseerde deelmarktstudies 


\section{SAMENVATTING}

Een belangrijke onderzoektaak van het Researchcentrum voor Onderwijs en Arbeidsmarkt bestaat uit het ontwikkelen van een informatiesysteem voor onderwijs en arbeidsmarkt. Voor een eerste versie van dit informatiesysteem is gebruik gemaakt van data die afkomstig zijn van de twee-jaarlijkse Arbeidskrachtentellingen die het CBS tot 1985 verrichtte. Een bezwaar van deze aanpak is dat er per opleidingsrichting weinig specifieke informatie wordt geboden. Om die reden wordt gezocht naar aanvullende gegevensbestanden die zijn gebaseerd op adressen- of ledenbestanden van beroepsverenigingen en verenigingen van afgestudeerden of onderzoeksresultaten van bijvoorbeeld loopbaanonderzoeken.

De belangrijkste informatie die voor het informatiesysteem nodig is, bestaat uit nauwkeurige gegevens over opleidingsniveau en -richting, het soort beroep of functie dat men uitoefent en de bedrijfstak waarin men werkzaam is. In dit werkdocument wordt verslag gedaan van een inventarisatie van bestanden met dit soort gegevens. Hierbij beperken wij ons tot databestanden die informatie zouden kunnen bevatten over de arbeidsmarktpositie van afgestudeerde academici per studierichting.

De belangrijkste conclusie is, dat er in eerste instantie weinig direkt in het informatiesysteem onderwijs-arbeidsmarkt in te passen gegevensbestanden of onderzoeksresultaten voorhanden zijn. De grootste belemmeringen worden gevormd door het dikwijls niet representatief zijn van de gegevens voor een studierichting als geheel en door het feit dat de gegevens over het soort beroep dat men uitoefent en de bedrijfstak waarin men werkzaam is, indien aanwezig, in zeer grove vorm zijn gecategoriseerd.

Weliswaar zijn er ook onderzoeksresultaten en adressenbestanden voorhanden waarin de voor ons noodzakelijke informatie wél op een verfijnde manier is vastgelegd, maar in die gevallen zijn veelal andere indelingen gebruikt dan de door het ROA gehanteerde CBS-standaardclassificaties. De meest plausibele redenen hiervoor lijken te zijn dat men ofwel onbekend is met de CBS-standaardindelingen, ofwel dat men deze té gedetailleerd of juist niet specifiek genoeg vindt. Teneinde aan deze bezwaren tegemoet te komen zou, op basis van de CBS-indelingen, een op onderdelen verder gedesaggregeerde indeling ontworpen en gepropageerd kunnen worden. 
Bij het volgen van afgestudeerden op de arbeidsmarkt spelen een aantal belemmerende factoren een rol. De belangrijkste hiervan is dat het contact tussen afgestudeerden en onderwijsinstelling, na het behalen van het diploma, dikwijls direkt is verbroken. Intermediaire organisaties als beroepsverenigingen en verenigingen van afgestudeerden nemen deze rol enigszins over. Om een beeld te vormen van de wijze waarop dergelijke organisaties te werk kunnen gaan, zijn de activiteiten van twee van deze organisatievormen uitgebreid beschreven: de Stichting Maatschappelijke Plaats Wageningse Afgestudeerden van de Landbouw Universiteit (LU) en de Association of Graduate Careers Advisory Services (AGCAS) uit Groot-Brittannië. 


\section{$\underline{\text { VERANTWOORDING }}$}

Een belangrijke onderzoekopdracht van het Researchcentrum voor Onderwijs en Arbeidsmarkt bestaat uit het ontwikkelen van een informatiesysteem onderwijs en arbeidsmarkt, zoals is beschreven in het ROA-onderzoekprogramma (ROA-R$1988 / 1)^{1}$. Dit systeem zou regelmatig (kwantitatieve) informatie moeten verschaffen over de arbeidsmarktperspectieven en uitwijkmogelijkheden van opleidingen en studierichtingen van alle onderwijsniveaus.

In het onderzoekprogramma wordt tevens melding gemaakt van een deelproject "inventarisatie en exploratie van aanvullende databestanden" (ROA-W-1988/2). Dit rapport is de eerste stap in het kader van dit deelproject. Vooralsnog wordt alleen aandacht geschonken aan de arbeidsmarktpositie van afgestudeerden uit het Wetenschappelijk Onderwijs. Met een vergelijkbare inventarisatie van databestanden uit het Hoger Beroeps Onderwijs is onlangs begonnen. De eerste resultaten daarvan zullen begin 1989 bekend zijn.

De hier gepresenteerde inventarisatie en rapportage stond onder leiding van prof. dr. J.A.M. Heijke en dr. A. de Grip. De uitvoering van het onderzoek en de verslaglegging ervan zijn gedaan door drs. J.W. van Dam met medewerking van M.A. Mortier.

1. Naar een informatiesysteem onderwijs-arbeidsmarkt, onderzoekprogramma 1988/1989, ROA-R-1988/1, Maastricht. 


\section{INLEIDING}

Het Researchcentrum voor Onderwijs en Arbeidsmarkt van de Rijksuniversiteit Limburg is in de zomer van 1986 van start gegaan. Het onderzoeksproject waarmee toen werd begonnen en waar thans ook nog aan wordt gewerkt, bestaat uit het ontwikkelen van een permanent informatiesysteem voor onderwijs en arbeidsmarkt. In eerste instantie zouden hiermee gegevens moeten worden voortgebracht over de arbeidsmarktperspectieven van opleidingen en beroepen, die een rol kunnen spelen bij de studie- en beroepskeuzevoorlichting van scholieren en studenten. De voortgebrachte informatie zou echter ook voor andere doeleinden gebruikt kunnen worden. Te denken valt aan capaciteitsplanning, onderwijsvoorzieningen, curriculum-evaluatie en -ontwikkeling, voorlichting en werving door onderwijsinstanties, de manpower-planning, recrutering en scholing van (toekomstige) werknemers door werkgevers, etcetera.

In het ROA-onderzoekprogramma $1988-1989^{2}$, wordt dieper ingegaan op de potentiële gebruiksmogelijkheden van een dergelijk informatiesysteem. Tevens wordt daarin uiteen gezet op welke wijze gewerkt wordt aan de totstandkoming ervan. Een belangrijke plaats wordt daarbij ingenomen door de basis gegevens waarmee de arbeidsmarktontwikkelingen worden geprognosticeerd.

De belangrijkste 'input' wordt vooralsnog gevormd door de statistische gegevens van het CBS over de aantallen werkenden naar functie, bedrijfstak, opleiding, leeftijd, geslacht en arbeidsduur. Deze CBS-cijfers kunnen echter niet nauwkeurig gedesaggregeerd worden. Daarnaast wordt echter getracht om andere bronnen van statistische gegevens op te sporen die een nauwkeuriger beeld geven van de arbeidsmarkt of het onderwijs. Daarbij wordt met name gedacht aan gegevens over de bestemming op de arbeidsmarkt van de uitstroom van het onderwijs.

In dit werkdocument wordt een begin gemaakt met het opsporen van aanvullende gegevensbronnen. Het is een eerste inventarisatie van de gegevensbestanden die er bestaan òver en onderzoeken die zijn verricht ónder afgestudeerden van het Wetenschappelijk Onderwijs in Nederland.

2. Naar een informatiesysteem onderwijs-arbeidsmarkt, onderzoekprogramma 1988/1989, ROA-R-1988/1, Maastricht. 
Deze beperking tot de arbeidsmarktpositie van academici heeft als reden dat verwacht mag worden dat deze het best in kaart is gebracht. Bovendien heeft dit te maken met de door het ROA gevolgde werkwijze welke erop neer komt dat eerst het hoogste onderwijssegment in het informatiesysteem wordt geĩntegreerd. Overigens is inmiddels begonnen met een vergelijkbare inventarisatie voor het Hoger Beroeps Onderwijs.

\subsection{Gevolgde werkwijze}

Sinds de oprichting van het ROA, in de zomer van 1986, is een archief met publikaties over het onderwerp onderwijs en arbeidsmarkt aangelegd. Uit tijdschriften, literatuuroverzichten, bestanden van andere bibliotheken, perspublikaties en uiteenlopende contacten is een verzameling van onderzoekverslagen opgebouwd over de positie van academici op de arbeidsmarkt.

De bronnen van deze publikaties vallen globaal uiteen in twee categorieën. Ten eerste de onderwijsorganisaties: universiteiten, faculteiten, vakgroepen en aanverwante instellingen zoals verenigingen van afgestudeerden. Ten tweede de beroepsorganisaties en -verenigingen.

Deze onderzoeksverslagen zijn geĩnventariseerd aan de hand van een aantal aandachtspunten. In de inleiding van hoofdstuk 3 zal hierop verder worden ingegaan. In een aantal gevallen is telefonisch om meer informatie gevraagd. Het ging daarbij vooral om vragen aan beroepsverenigingen en verenigingen van afgestudeerden over welke gegevens zij beschikken en op welke wijze deze zijn gerubriceerd. Een aantal potentiële gegevensbronnen is op deze wijze boven tafel gekomen. Momenteel wordt gewerkt aan een meer systematische benadering van deze organisaties.

\subsection{Opzet van dit werkdocument}

$\mathrm{Na}$ dit inleidende hoofdstuk wordt in hoofdstuk 2 verder ingegaan op de ontwikkeling van het informatiesysteem voor onderwijs en arbeidsmarkt. In de paragrafen 2.4 en 2.5 zal dan met name aandacht worden gegeven aan de benodigde informatie en de criteria waaraan deze informatie moet voldoen. Met behulp van deze criteria wordt een inventarisatie gemaakt van de informatie die bij de eerder genoemde organisaties voorhanden is en die van 
belang kan zijn voor het informatiesysteem onderwijs-arbeidsmarkt. De resultaten van deze inventarisatie worden in hoofdstuk 3 weergegeven. In paragraaf 3.2 wordt per studie of databestand aangegeven of deze in beginse 1 bruikbare informatie bevat voor het informatiesysteem. Het gaat daarbij alleen om het eindoordeel of een bestand of onderzoek in beginsel bruikbare informatie bevat of niet. Een uitgebreider verslag van de inventarisatie is als Bijlage I bij dit rapport opgenomen. In paragraaf 3.3 worden per criterium een aantal conclusies getrokken.

De belangrijkste conclusie is dat er geen gegevensbronnen beschikbaar zijn over de arbeidsmarktpositie van afgestudeerden, die voldoen aan alle door ons gestelde criteria. Eén van de meest omvangrijke uitstroomonderzoeken die er bestaan over afgestudeerden van één universiteit, en die tevens het beste tegemoet komt onze criteria, is het vijfjaarlijkse loopbaanonderzoek van de Stichting Maatschappelijke Plaats Wageningse Afgestudeerden (MPW). In hoofdstuk 4 wordt uitvoerig ingegaan op de inhoud, totstandkoming en bruikbaarheid van deze loopbaanonderzoeken. De door MPW gehanteerde indelingen en classificaties zijn als Bijlage II in dit werkdocument opgenomen.

De situatie in Nederland is nog verre van ideaal, als het gaat om een uniforme wijze van gegevensverzameling over de positie van afgestudeerden op de arbeidsmarkt. In Groot-Brittannië bestaat er daarentegen wel een geĩnstitutionaliseerde systematische gegevensverzameling. Sinds 1968 wordt daar onder álle afgestudeerden van de 52 universiteiten en technische hogescholen dezelfde (basis) vragenlijst afgenomen. Deze enquête wordt uitgevoerd door de aan iedere universiteit verbonden Careers Advisory Service onder auspicieën van de Association of Graduate Careers Advisory Services en de Universities Statistical Records. In hoofdstuk 5 wordt uitvoerig ingegaan op de inhoud, totstandkoming en bruikbaarheid van deze 'first destination surveys'. De gehanteerde definities en classificaties worden weergegeven in Bijlage III. 


\section{NAAR EEN INFORMATIESYSTEEM ONDERWIJS - ARBEIDSMARKT}

\subsection{Uitgangspunten voor het informatiesysteem}

In het ROA-onderzoekprogramma $1987 / 1988^{3}$ worden de volgende uitgangspunten genoemd voor de ontwikkeling van het informatiesysteem onderwijs en arbeidsmarkt:

1. Het systeem moet informatie opleveren welke bruikbaar is voor de studieen beroepskeuzevoorlichting ten behoeve van scholieren en studenten in respectievelijk het voortgezet en hoger onderwijs.

2. De te verschaffen informatie moet van kwantitatieve aard zijn. Het gaat daarbij om het verschaffen van gegevens over de ontwikkeling van de werkgelegenheid in de verschillende sectoren van de arbeidsmarkt, de ontwikkeling van de onderscheiden categorieën van de beroepsbevolking (naar bijvoorbeeld beroep en opleiding), de doorstroming van leerlingen door de diverse delen van het onderwijs en dergelijke.

3. Er moet optimaal profijt worden getrokken van reeds beschikbare kwantitatieve gegevens en bestaande kennis om de ontbrekende gegevens beschikbaar te maken.

4. Het informatiesysteem moet een duurzaam karakter hebben. Het gaat om het ontwikkelen van een instrument dat de benodigde gegevens met regelmatige tussenpozen kan verschaffen, op basis van actuele inzichten.

\subsection{Ontwikkelingsfasen van het informatiesysteem}

De ontwikkeling van het informatiesysteem onderwijs-arbeidsmarkt geschiedt in verschillende fasen De eerste fase betreft het ontwikkelen van een voorlopig informatiesysteem, op basis van direct beschikbare gegevens en op korte termijn te benutten kennis. In de tweede fase moet een programma van activiteiten worden ontwikkeld, dat is gericht op een geleidelijke uitbouw en verbetering van het informatiesysteem. Een eerste versie van het informa-

3. Naar een informatiesysteem onderwijs-arbeidsmarkt, onderzoekprogramma 1987/1988, ROA-R-1987/2, Maastricht. 
matiesysteem, gebaseerd op het direkt beschikbare CBS-datamateriaal, is inmiddels tot stand gekomen ${ }^{4}$. Dit werkdocument moet worden geplaatst in het kader van de uitvoering van de tweede fase.

Met betrekking tot het Wetenschappelijk Onderwijs kan ook worden gewezen op een pilot-onderzoek dat in opdracht van het Ministerie van Onderwijs en Wetenschappen wordt verricht naar de mogelijkheden om regelmatig onderzoek te doen onder afgestudeerden van universiteiten. Deze pilot-study beperkt zich in eerste instantie tot de Faculteit der Gezondheidswetenschappen van de Rijksuniversiteit Limburg. De pilot-study is er eveneens op gericht een aanvullende gegevensbron voor het informatiesysteem onderwijs-arbeidsmarkt te ontwikkelen.

\subsection{Doeleinden van het informatiesysteem: de outputvariabelen}

Met het informatiesysteem worden vooralsnog twee belangrijke gebruiksdoelen gediend: ten eerste de 'monitoring' van de actuele situatie op de'arbeidsmarkt en ten tweede het ontwikkelen van prognoses van de arbeidsmarktperspectieven van opleidingen en beroepen.

De 'monitoringfunctie' is met name gericht op het zo nauwkeurig mogelijk volgen van actuele ontwikkelingen in de aansluiting van afzonderlijke opleidingen en studierichtingen op de arbeidsmarkt.

Bij het opstellen van prognoses wordt uitgegaan van een horizon van vijf jaar. Hierdoor zouden ze een relevante rol kunnen spelen bij de studie- en beroepskeuzevoorlichting. Voor de volgende soorten gegevens zijn prognoses ontwikkeld:

- ontwikkeling van de werkgelegenheid naar beroep en naar universitair afstudeerrichting;

- vervangingsvraag naar beroep en opleiding;

- confrontatie van de werkgelegenheidsprognoses naar universitaire afstudeerrichting met prognoses van de uitstroom van afgestudeerden uit het universitaire onderwijs.

4. A. de Grip, J.A.M. Heijke, R.J.P. Dekker en L.F.M. Groot: De arbeidsmarkt naar beroep en de positie van academici daarbinnen, ROA-W-1987/1, Maastricht. 


\subsection{De benodigde gegevens voor het informatiesysteem}

De informatie die nodig is voor het informatiesysteem onderwijs-arbeidsmarkt is afhankelijk van zowel de doelstelling als de doelgroep. Vooralsnog wordt er van uitgegaan dat het gaat om een informatiesysteem dat gebruikt kan worden bij de studie- en beroepskeuzevoorlichting aan scholieren en studenten.

Om een dergelijk informatiesysteem op te kunnen zetten zijn onder meer verschillende gegevens nodig over de beroepsbevolking. De belangrijkste gegevens die daarover verkregen kunnen worden zijn:

- opleidingsrichting en -niveau;

- eerste bestemming na het afronden van een opleiding en de aard van deze eerste bestemming;

Indien men werkt:

- functie en functieniveau;

- functie-inhoud, (te verrichten werkzaamheden);

- werkgever en bedrijfstak;

Vervolgens zijn er een aantal basisgegevens van secundair belang:

- benodigde/gevraagde vooropleiding;

- (eventueel) benodigde hoeveelheid werkervaring;

- (eventueel) benodigde aanvullende cursussen;

- aanvangssalaris;

\subsection{Te stellen eisen aan het datamateriaal}

Aan het datamateriaal dat gebruikt zal worden voor een dergelijk informatiesysteem kunnen de volgende eisen worden gesteld:
a. Representativiteit
b. Interne- en externe consistentie
C. Koppelbaarheid aan andere gegevensbestanden
d. Actualiteit
e. Toegankelijkheid
f. Periodieke herhaling 
Deze eisen kunnen als volgt worden toegelicht:

ad a. Vanzelfsprekend kunnen alleen die gegevens gebruikt worden die op een verantwoorde wijze zijn verzameld en bewerkt. Zo dienen de onderzoekspopulaties een getrouwe afspiegeling te vormen van de totale populatie waarover gegevens worden verzameld (representativiteit). Tevens dient de wijze waarop de gegevens worden verzameld, te voldoen aan de methodische vereisten van validiteit en betrouwbaarheid. Tenslotte dient de wijze waarop de meetresultaten worden verwerkt statistisch verantwoord te zijn.

ad b. De bruikbaarheid van door anderen gegenereerde informatie hangt ook af van de vraag of er van consistentie sprake is. Met interne consistentie wordt bedoeld dat er geen sprake mag zijn van witte plekken of dubbeltellingen in het databestand. Onder externe consistentie wordt de vergelijkbaarheid van het ene databestand met andere bestanden begrepen. Dit is vooral afhankelijk van de vergelijkbaarheid van definities en onderzoekspopulaties.

ad c. Eveneens een belangrijk criterium wordt gevormd door de vraag of de aanvullende gegevens wel op een dusdanige wijze zijn geordend en ingedeeld dat een vergelijking met de in het informatiesysteem gehanteerde indeling mogelijk is. Hier wordt gedoeld op de onderlinge koppelbaarheid van de bestanden. Indien er geen sprake is van een hanteerbare indeling naar functie, opleiding en bedrijfstak waarin men werkzaam is, komt de vraag aan de orde in welke basisvorm de aanvullende gegevens beschikbaar zijn. Zijn de individuele gegevens nog voorhanden (in de vorm van antwoorden op open vragen) dan is hercodering nog mogelijk. Zij het dat dit een zeer bewerkelijke zaak is. Zijn de individuele gegevens echter alleen nog in geabstraheerde vorm aanwezig of alleen nog in de vorm van een overzicht van de samengevoegde antwoorden, dan is de analyse van dergelijk secundair onderzoeksmateriaal voor inpassing in het informatiesysteem niet erg zinvol.

Uitgangspunt voor het informatiesysteem voor onderwijs en arbeidsmarkt wordt gevormd door de Standaard Classificaties van het Centraal Bureau voor de Statistiek (CBS) die op hun beurt weer zijn geënt op internationale classificaties. Alleen onderzoeksresultaten of adressenbestanden die terug zijn te voeren tot deze Standaard Classificaties zijn in te voegen in het informatiesysteem. 
ad d. Een criterium dat nauwelijks toegelicht hoeft te worden is dat van de actualiteit. Vanwege de snelle ontwikkelingen binnen de samenleving in haar algemeenheid en op de arbeidsmarkt in het bijzonder, zijn data die meer dan vijf jaar oud zijn, nauwelijks nog zelfstandig bruikbaar voor analyse. Dit is overigens niet het geval indien het gaat om de resultaten van regelmatig herhaalde metingen, die onderling vergelijkbaar zijn. In dat geval kunnen tijdreeksanalyses nuttige inzichten opleveren.

ad e. Een belangrijk vereiste is de toegankelijkheid van de databestanden. Dit is vooral afhankelijk van de vraag in welke vorm de data aanwezig zijn (kaartenbak, schijf, tape, oorspronkelijke vragenlijst) en de vraag of er formele- of juridische redenen zijn die het gebruik van de data in de weg staan. Gedacht kan worden aan privacy reglementen, statuten, gedragscodes en dergelijke.

ad f. Het zal bovendien duidelijk zijn dat het voor het informatiesysteem het meest wenselijk is, indien er sprake is van een regelmatige herhaling van de gegevensverzameling. Met andere woorden: indien de ontwikkelingen in het betreffende arbeidsmarktsegment regelmatig op dezelfde wijze in kaart worden gebracht. Pas dan is er feitelijk sprake van een systematische monitoring van de arbeidsmarktsituatie.

Tot zover een toelichting op de belangrijkste criteria. In hoofdstuk 3.3 van dit werkdocument zal besproken worden in hoeverre de bovengenoemde criteria een belemmering vormen voor de bruikbaarheid van de door ons geĩnventariseerde onderzoeken. 


\section{EEN INVENTARISATIE VAN ARBEIDSMARKTONDERZOEK ONDER ACADEMICI}

\subsection{Inleiding}

In ons land worden door tal van organisaties gegevens verzameld over de arbeidsmarktpositie van academici. In dit hoofdstuk staat de vraag centraal of deze zogeheten deelmarktonderzoeken bruikbare informatie opleveren voor het informatiesysteem onderwijs - arbeidsmarkt. Het gaat om onderzoek, gegevensverzameling of adresregistraties die zijn verricht door universiteiten, faculteiten of vakgroepen of door verenigingen van afgestudeerden en beroepsverenigingen. Centraal staat hier de vraag of deze deelmarktonderzoeken voldoen aan de in het voorgaande hoofdstuk beschreven criteria. Met andere woorden: zijn er mogelijkheden om met de onderzoeksresultaten of het geĩnventariseerde databestand het informatiesysteem aan te vullen? In de navolgende inventarisatie wordt alleen een globale eindconclusie (wel/niet bruikbare gegevens) weergegeven. Een meer uitgebreide beschrijving van de resultaten van de genoemde inventarisatie is als Bijlage I bij dit werkdocument opgenomen.

De opbouw van dit hoofdstuk is als volgt. In paragraaf 3.2 komen de resultaten van de inventarisatie aan de orde. Deze onderzoeken en gegevensbestanden van verenigingen hebben gemeen dat zij informatie bevatten over één of meerdere jaargangen afgestudeerden of over beroepsgroepen met één bepaalde studierichting. Vaak hebben deze onderzoeken een incidenteel karakter en een beperkte onderzoekspopulatie. De indeling en volgorde waarin deze deelmarktonderzoeken besproken worden komt overeen met de Standaard Onderwijs Indeling van het CBS.

Hier, op deze plaats, kan al gezegd worden dat de meeste van de geĩnventariseerde onderzoeken niet of nauwelijks voldoen aan de gestelde criteria. Voor ledenbestanden van beroepsverenigingen en verenigingen van afgestudeerden ligt dit iets genuanceerder. In een aantal gevallen zouden deze gegevensbestanden, na hercodering, een bruikbare aanvulling van het informatiesysteem kunnen vormen.

Uiteraard dringt zich dan de vraag op om welke redenen de aangetroffen deelmarktonderzoeken voor ons weinig bruikbare resultaten opleverden. In paragraaf 3.3 worden de eerder geformuleerde criteria nog eens afzonderlijk 
bekeken aan de hand van de geĩnventariseerde onderzoeken. De vereisten van representativiteit en de koppelbaarheid aan andere bestanden blijken doorgaans de grootste struikelblokken te zijn.

\subsection{Resultaten inventarisatie deelmarktonderzoeken}

De inventarisatie heeft plaats gevonden aan de hand van de criteria zoals deze in het voorgaande hoofdstuk zijn geformuleerd en toegelicht. Teneinde een overzicht te krijgen dat ook als naslagwerk kan dienen, is getracht per onderzoek een reeks vragen te beantwoorden. De antwoorden op deze vragen geven de informatie die nodig is om aan de genoemde criteria (representativiteit, consistentie, koppelbaarheid, actualiteit, toegankelijkheid en herhaling) te toetsen. Het betrof de volgende vragen:

1. Door welke organisatie is het onderzoek verricht? (c.q. wordt het bestand bijgehouden?)

2. Door wie en wanneer? Eenmalig of regelmatig?

3. Om welke onderzoekspopulatie gaat het?

4. Is er sprake van een representatief onderzoek?

5. Welke dekkingsgraad is bereikt en op welke wijze is het contact met de onderzoekspopulatie onderhouden of tot stand gekomen?

6. Wat is de doelstelling van het onderzoek?

7. Welke onderzoeksmethode is gehanteerd?

8. Wat waren de belangrijkste onderzoeksvragen en -items?

9. Welke definities en classificaties zijn gehanteerd en zijn er mogelijkheden om deze te vertalen naar CBS-classificaties?

10. Zijn de onderzoeksresultaten bruikbaar voor het informatiesysteem onderwijs-arbeidsmarkt?

Vanuit deze vragen is gekeken naar onderzoeken onder afgestudeerde academici die antwoord geven op de vraag: waar zijn afgestudeerde academici terechtgekomen? In een aantal gevallen is weliswaar geen sprake van een onderzoek onder afgestudeerden of academici maar bestaat er wel een bestand met gegevens over adres, functie en werkgever. Het betreft dan veelal de ledenadministratie van een beroepsvereniging of van een vereniging van afgestudeerden. Ook hiervan is zoveel mogelijk melding gemaakt. Vacature-enquêtes onder werkgevers, onderzoeken naar toekomstverwachtingen van werkgevers, beroepsvoorkeuren van studenten, prognoses van de arbeidsmarktontwikkelingen 
afkomstig van diverse instanties, etcetera, zijn om die reden niet in deze inventarisatie opgenomen. 


\section{LETTEREN:}

Geen direct bruikbare gegevensbestanden aangetroffen.

AGRARISCHE WETENSCHAPPEN EN HUISHOUDKUNDE:

Zowel het adressenbestand van het Nederlands Instituut van Landbouwkundig Ingenieurs (NILI) als de resultaten van de vijf-jaarlijkse loopbaanenquête van de Stichting Maatschappelijke Plaats Wageningse Afgestudeerden van het NILI zijn, na hercodering, geschikt om op te nemen.

WIS- en NATUURKUNDE:

Geen direct bruikbare gegevensbestanden aangetroffen:

- In het ledenbestand van de Nederlandse Natuurkundige Vereniging (NNV) (3500 leden) zijn geen gegevens opgenomen over beroep en bedrijfssector.

- Bij de sectie Biochemie en Biofysica van de Koninklijke Nederlandse Akademie van Wetenschappen (KNAW) is een eenmalig onderzoek verricht, waarvan de resultaten niet bruikbaar zijn: (nauwelijks gegevens over beroep en bedrijfssector).

- De Nederlandse Vereniging voor Biochemie (NVB) heeft 2000 leden: ca.60 à $80 \%$ van totale populatie is lid. Voor het adressenbestand gelden dezelfde bezwaren als voor het KNAW-onderzoek.

- De Koninklijke Nederlandse Chemische Vereniging (KNCV) heeft 11.000 leden, waarvan naar schatting 7.000 academici. Circa $70 \%$ van de afgestudeerde chemici/scheikundigen is hiervan lid. De drie-á vierjaarlijkse ledenenquête levert alleen bruikbare informatie op over de bedrijfssector waarin men werkzaam is. Wellicht dat het ledenbestand een nuttige aanvulling biedt.

\section{TECHNISCHE WETENSCHAPPEN:}

Geen direct bruikbare gegevensbestanden aangetroffen:

- Wellicht doen zich op middellange termijn wél mogelijkheden voor aangezien de technische universiteiten voorbereidingen treffen om adressenbestanden van afgestudeerden op te zetten. 
- Het ledenbestand van het Koninklijk Instituut van Ingenieurs (KIVI) (12.000 werkzame leden ten opzichte van 42.000 totale populatie) biedt eventueel mogelijkheden tot systematische gegevensverzameling. Momenteel echter is de classificatie van beroepen en bedrijfssectoren zeer beperkt.

MEDISCHE WETENSCHAPPEN:

Geen direct bruikbare gegevensbestanden aangetroffen:

- Bij de Koninklijke Nederlandse Maatschappij voor Diergeneeskunde (KNMD) zijn gegevens bekend over de totale populatie afgestudeerden in de diergeneeskunde. De 3.000 werkzame leden (circa $85 \%$ van de totale populatie) zijn geregisteerd over 12 beroeps- en bedrijfsgroepen.

- Daarnaast zijn bij diverse beroepsverenigingen en instanties gegevens over geregistreerde beroepsbeoefenaren voorhanden. Het betreft echter steeds deelpopulaties die geen representatief beeld geven van de bestemming van alle afgestudeerden van een bepalde studierichting.

\section{GEZONDHEIDSWETENSCHAPPEN:}

Geen direkt bruikbare gegevensbestanden aangetroffen.

- Wel heeft de Faculteit der Gezondheidswetenschappen van de RL een enquête onder 273 afgestudeerden gehouden. De ruwe data (ingevulde vrageniijsten) zijn na hercodering, bruikbaar.

- De Nederlandse Vereniging voor Gezondheidswetenschappen heeft een adressenbestand. Onbekend is welke gegevens en in welke vorm zijn geregistreerd.

ECONOMISCHE WETENSCHAPPEN En BEDRIJFSKUNDE (drs.):

Het adressenbestand van de Stichting Landelijke Adresiijst Economisten biedt mogelijkheden tot codering naar beroep en bedrijfssector en daarmee tot aanvulling van het informatiesysteem. Naar schatting is twee-derde van de werkzame economen in het adressenbestand opgenomen. Overigens is nog niet bekend of hierdoor een representatief beeld kan worden verkregen van alle afgestudeerde economen. 
De Faculteiten Bedrijfskunde beschikken over verenigingen van afgestudeerden met adressenbestanden. Het is nog onbekend welke mogelijkheden dit biedt.

ECONOMETRIE, AKTUARIAAT en BEDRIJFSKUNDE (ir.):

De Vereniging van Afgestudeerde Econometristen Tilburg (VAET) beschikt over bruikbare gegevens over 350 leden van de 420 afgestudeerden. Zowel in ongecodeerde als in gecodeerde vorm (in 22 branches en 13 functies). (Her)codering is wel noodzakelijk.

De verenigingen van afgestudeerde bedrijfskundigen van de Technische Universiteiten beschikken over bestanden met relevante gegevens. Deze zijn echter niet direct bruikbaar.

RECHTEN:

Geen direct bruikbare gegevensbestanden aangetroffen:

De faculteit Rechten van de EUR houdt sedert 1986 jaarlijks een enquête onder recent afgestudeerden. Indien de ongecodeerde vragenlijsten beschikbaar zijn zouden ze, na codering, een nuttige aanvulling kunnen vormen voor het informatiesysteem.

De resultaten van de enquête "Rechtenstudie en werk" onder 2.425 recent afgestudeerden van drie faculteiten (RL, RUL, RUG) kunnen wellicht bruikbaar zijn voor het informatiesysteem. De belangrijkste beperking wordt echter gevormd door de beperkte respons (circa 45\%). Er moet worden nagegaan of dit van invloed is geweest op de representativiteit. De bruikbaarheid hangt bovendien af van de wijze waarop de antwoorden op de open vraag met betrekking tot het uitgeoefende beroep worden verwerkt.

SOCIAAL-CULTURELE WETENSCHAPPEN:

Geen direct bruikbare gegevensbestanden aangetroffen:

Onbekend is welke nauwkeurigheid de dataverzameling van prof. IJzerman (RUG) over de arbeidsmarktpositie van sociologen heeft. 


\subsection{CONCLUSIES}

In deze paragraaf komen de belangrijkste conclusies aan de orde die getrokken kunnen worden na toetsing van de onderzoeken en adressen- c.q. databestanden, aan de in paragraaf 2.4. eerder omschreven criteria.

Per criterium kan het volgende worden geconcludeerd:

1. Bijna alle onderzoeken en ledenbestanden zijn ofwel aantoonbaar niet representatief, ofwel het is onbekend in hoeverre ze wèl representatief zijn. Het is bijvoorbeeld aannemelijk te veronderstellen dat niet werkenden minder snel lid zullen worden van een beroepsvereniging. Eveneens zullen niet-werkenden minder snel geneigd zijn om mee te werken aan een loopbaanonderzoek. De tot op heden aangetroffen deelmarktonderzoeken en ledenbestanden kunnen dan ook nauwelijks bijdragen aan een verfijning van bijvoorbeeld werkloosheidscijfers en werkgelegenheidsprognoses. Vooralsnog lijkt de aanvullende waarde van de genoemde extra informatiebronnen vooral te liggen in de mogelijkheid tot het verfijnen van de verdeling van de werkenden over beroepsgroepen en bedrijfssectoren.

2. Met betrekking tot de consistentie is onderscheid gemaakt tussen de interne- en externe consistentie. Over de interne consistentie (geen 'witte vlekken' en dubbeltellingen) kan op dit ogenblik nog weinig worden gezegd omdat diverse adressenbestanden nog niet daadwerkelijk zijn ingezien. Over de externe consistentie kan geconcludeerd worden dat databestanden niet op elkaar aansluiten en derhalve witte vlekken en dubbeltellingen veroorzaken doordat zeer uiteenlopende definities en omschrijvingen van ledenbestanden en onderzoekspopulaties worden gehanteerd.

Geconstateerd kan worden dat bij veel onderzoeken nogal uiteenlopende definities worden gehanteerd van werkgelegenheid, werkloosheid, betaalde arbeid, etcetera. Bovendien is bij (half-) gesloten antwoordcategorieën nogal eens sprake van niet-sluitende of overlappende antwoordmogelijkheden. Naar onze mening wordt de vergelijkbaarheid en inpasbaarheid van onderzoeksresultaten sterk nadelig beinnloed door uiteenlopende definities en antwoordmogelijkheden. 
3. Met betrekking tot de koppelbaarheid van de databestanden aan de in het informatiesysteem gebruikte standaardclassificaties is al eerder opgemerkt dat dit een groot struikelblok vormt voor de bruikbaarheid van beschikbare deelmarktgegevens. Zelden is een faculteit of beroepsvereniging aangetroffen die voor de registratie van afgestudeerden c.q. leden gebruik maakt van een van de CBS-classificatie afgeleide indeling. Laat staan dat dit voor alle drie de door ons benodigde soorten gegevens (opleidings-, beroep- en bedrijfssector) is gedaan. Doorgaans worden eigen indelingen gebruikt. Deze variëren van indelingen met drie, vier of vijf categorieëen tot zeer verfijnde classificaties met enige tientallen keuzemogelijkheden. De bruikbaarheid van gegevens die zijn geclassificeerd volgens eigen indelingen, is echter niet alleen afhankelijk van de manier waarop deze gegevens zijn geclassificeerd, maar ook van de wijze waarop ze zijn vastgelegd en verwerkt (papier/kaart, schijf of tape). In het geval de ruwe data zich in de vorm van antwoorden op open vragen op de oorspronkelijke vragenlijsten bevinden, is hercodering en classificatie weliswaar mogelijk maar zeer bewerkelijk. In dat geval komt uiteraard de vraag naar boven hoe het "gegevensbestand" scoort ten opzichte van de andere criteria.

Echter, in het geval dat de data zich op magneetband bevinden en zijn gerubriceerd, per kenmerk, in een groot aantal categorieën, wordt hercodering aanzienlijk gecompliceerder. Dan komt de vraag aan de orde hoe de oorspronkelijke classificatie zich verhoudt tot de standaardclassificaties van het CBS en of hercodering mogelijk is. Doorgaans zal dit niet het geval zijn omdat het CBS veel meer categorieën onderscheidt dan in de geĩnventariseerde deelmarktstudies wordt gedaan. Aan de andere kant moet ook worden opgemerkt dat de door het CBS gehanteerde indelingen niet erg geschikt zijn voor universiteiten en beroepsverenigingen van academici. Zo is de Standaard Bedrijfs Indeling (SBI) bijvoorbeeld enorm verfijnd voor economische sectoren waar nauwelijks academici werkzaam zijn. Maar voor de publieke sector, waar het merendeel van de academici werkt, is de SBI niet erg verfijnd.

De conclusie dringt zich op dat zo spoedig mogelijk begonnen moet worden met het ontwikkelen van een in aanvulling en in aansluiting op de CBS classificaties, éénsluitend classificatiesysteem dat zowel voor het formatiesysteem van het ROA als ook voor de diverse gegevensverzamelende 
andere organisaties adequat is.

4. Een vierde criterium betreft de actualiteit van de aanvullende gegevens. Opgemerkt moet worden dat voor onze inventarisatie alleen die data in aanmerking kwamen die niet langer dan vier jaar geleden bijeen zijn gebracht. Hierbinnen valt overigens het grootste deel van de ons bekende onderzoeken.

5. Alle theoretische beschouwingen over de mogelijkheden van inpassing ten spijt, lijkt een belangrijk struikelblok te worden gevormd door het praktische vereiste van de toegankelijkheid. Zeker nu geconstateerd is dat voor àlle onderzoeksresultaten en databestanden hercodering nodig is, voordat ze een zinvolle aanvulling van het informatiesysteem kunnen vormen. Veel zal dan af gaan hangen van de bereidheid van de diverse organisaties om hun dataverzameling op een andere wijze te gaan classificeren. Het zal duidelijk zijn dat dit alleen zal gebeuren als deze organisaties overtuigd kunnen worden van het algemene nut en het belang dat zij er zelf bij hebben.

6. Het zesde criterium betreft de vraag of een onderzoek eenmalig is verricht, of dat er enige regelmaat aanwezig is in de dataverzameling. Vanzelfsprekend zijn voornamelijk de periodiek verzamelde gegevens interessant voor het informatiesysteem onderwijs en arbeidsmarkt. Verheugend is het dan ook om te constateren dat steeds meer organisaties (onderwijsinstellingen en beroepsverenigingen) oog krijgen voor de arbeidsmarktpositie van hun afgestudeerden en zich derhalve grotere inspanningen getroosten om vaker adressenbestanden op te zetten en te actualiseren.

In hoofdstuk 6 zal verder op de bovenstaande conclusies worden ingegaan. 


\section{STICHTING MAATSCHAPPELIJKE PLAATS WAGENINGSE AFGESTUDEERDEN}

In tegenstelling tot bijvoorbeeld de Anglo-Saksische landen is in ons land nauwelijks sprake van regelmatig onderzoek onder afgestudeerden van universiteiten. Alleen de Stichting Maatschappelijke Plaats Wageningse Afgestudeerden (MPW), die momenteel bezig is met het vierde loopbaan-onderzoek onder álle afgestudeerden van de Landbouw Universiteit Wageningen (LU), werkt vanuit een dergelijke systematische aanpak. Zo wordt een omvangrijk adressenbestand van alle afgestudeerden van de Landbouw Universiteit bijgehouden. Vanwege de omvang van de onderzoekspopulatie, de regelmaat vàn en ervaringen mèt het onderzoek, en het geĩnstitutionaliseerde organisatorische kader waarin de MPW-onderzoeken plaats vinden, wordt in dit hoofdstuk uitvoerig stilgestaan bij het 5-jaarlijkse MPW-loopbaanonderzoek in combinatie met het jaarlijks up-to-date houden van het adressenbestand. Om een goede vergelijking te kunnen maken met de in Bijlage I beschreven andere onderzoeken, is gekozen voor dezelfde reeks aandachtspunten. Zij het dat deze hier veel uitgebreider aan de orde zullen komen.

\section{Wie verricht het onderzoek?}

De beroepsvereniging voor landbouwkundig ingenieurs, het Nederlands Instituut van Landbouwkundig Ingenieurs (NILI), besloot in het begin van de zeventiger jaren, om de ontwikkelingen op de arbeidsmarkt voor landbouwkundig ingenieurs beter in het oog te houden. Daartoe werd in 1973 een aparte organisatie opgezet: de Stichting Maatschappelijke Plaats Wageningse Afgestudeerden (MPW). Eén van de regelmatig terugkerende activiteiten van deze stichting is het 5-jaarlijkse loopbaanonderzoek onder afgestudeerde landbouwkundig ingenieurs waarmee in 1973 werd begonnen. Ook wordt door het NILI jaarlijks een adreslijst uitgegeven. Voor het up-to-date houden hiervan wordt jaarlijks aan alle leden een kaart gestuurd met daarop 22 verschillende gegevens (naam, adres, werkgever, functiecode, marktcode etcetera). Gevraagd wordt om eventueel gewijzigde gegevens te verbeteren en de kaart te frankeren en te retourneren.

Een van de doelstellingen van het MPW is het meer doorzichtig maken van de arbeidsmarkt voor afgestudeerden van de Landbouw Universiteit Wageningen (LU). Hiervoor is het niet voldoende om een momentopname te geven, maar een beeld van de 'ontwikkelingen die zich op de arbeidsmrkt voordoen en de eisen 
die deze stelt aan de afgestudeerde van nu en straks' 5 .

2. Doelstellingen van het MPW-onderzoek:

Volgens het MPW worden met het vijf-jaarlijkse loopbaanonderzoek onder afgestudeerden de volgende doelstellingen nagestreefd:

- aangeven welke plaats de LU-ingenieur op de arbeidsmarkt inneemt en welke ontwikkelingen zich hebben voorgedaan in de verschillende marktsectoren;

- beschrijven van de loopbanen van LU-ingenieurs;

- het verkrijgen van inzicht in de aansluiting van opleiding en de beroepspraktijk van LU-ingenieurs;

- Evaluatie van nieuwe studieprogramma's met behulp van zo aktueel mogelijke informatie omtrent de positie van afgestudeerden op de arbeidsmarkt en de aansluiting van studie en beroepspraktijk.

3. Doelgroep:

Het loopbaanonderzoek wordt gehouden ten behoeve van de voorlichting aan de volgende doelgroepen:

- (aankomende) studenten;

- Landbouw Universiteit;

- afgestudeerden;

- werkgevers;

- instanties op het gebied van onderwijs en arbeidsmarkt.

4. Onderzoekspopulatie:

Het MPW-10opbaanonderzoek in 1983 richtte zich op alle afgestudeerden van de LU vanaf het studiejaar 1940, waarvan een adres bekend was bij het NILI, met uitzondering van degenen waarvan men wist dat ze overleden of gepensioneerd waren. Daarbij moet bedacht worden dat de 'organisatiegraad' van Wageningse afgestudeerden zeer groot is: slechts van circa $5 \%$ van de in de periode 1940-'83 afgestudeerde Wageningse ingenieurs is het adres niet bekend.

5. Stichting Maatschappelijke Plaats Wageningse Afgestudeerden/NILI, Loopbaanenquête 1983, Wageningen, 1985. 
5. Met welke regelmaat?

Sedert 1973 vindt er iedere vijf jaar een loopbaanenquête plaats. Daarnaast worden er regelmatig deelmarktonderzoeken verricht (vrouwen, speciale studierichtingen etcetera).

\section{Onderzoeksvragen:}

De onderzoeksvragen in de loopbaanenquête komen overeen met de doelstellingen van het onderzoek. Deze kwamen hierboven al aan de orde. Een lijst met de onderzoeksitems is opgenomen in Bijlage II.

7. Wijze van informatieverzameling en -verwerking

Hoewel de gehanteerde onderzoeksmethode, een schriftelijke enquête, in de loop der jaren ongewijzigd is gebleven, is de indeling van de vragenlijst en de wijze van verwerken in 1988 gewijzigd ten opzichte van 1983. In 1983 werd gebruik gemaakt van een schriftelijke enquête met schriftelijke rappellering. De respondenten hoefden alléén een antwoordkaart met gesloten antwoordcategoriëen terug te sturen. Het invoeren van de resultaten gebeurde met een Optical Mark Reader en voor de verwerking werd gebruik gemaakt van SPSS. Ook in 1988 zal gebruik worden gemaakt van een schriftelijke enquête met een schriftelijke rappellering. De antwoorden zullen op het enquêteformulier zélf moeten worden aangegeven. Ook zijn er veel open vragen. Het invoeren, ver- en bewerken zal met de CBS-programmatuur 'BLAISE' gebeuren.

\section{Definities en classificaties}

Eén van de redenen waarom de vijf-jaarlijkse loopbaanenquête van het MPW zich onderscheidt van de andere onderzoeken ligt in de strikte definiëring van een aantal essentiële begrippen. Zo worden òfwel in de vragenlijst zelf, òfwel in de toelichting op de vragenlijst, de volgende begrippen gedefinieerd: ( zie Bijlage II):

- functie;

- vaste aanstelling;

- tijdelijke aanstelling;

- free-lance werk;

- pro deo werk; 
- marktsector;

- werkorganisatie;

- functieverandering.

Toch zijn de resultaten van de MPW-enquête door de eigen definiëring slechts gedeeltelijk vergelijkbaar met andere gegevens. Naast verschillen die ontstaan doordat niet alle werkzoekenden zich laten inschrijven bij het $G A B$, kunnen verschillen in werkloosheidscijfers ook ontstaan doordat verschillende definities van 'werkloosheid' gehanteerd worden. Zo wordt in de MPW-enquête iedereen die geen betaalde functie heeft, aangemerkt als werkloos. Wél is van deze werklozen bekend of zij actief op zoek zijn naar een werkkring.

Om de actuele arbeidssituatie te achterhalen, is in de vragenlijst een vraag opgenomen met 10 antwoordmogelijkheden (zie Bijlage II). Begrippen die niet éénduidig zijn te interpreteren worden zodanig gedefinieerd dat een volledige reeks van elkaar uitsluitende antwoordcategorieën ontstaat.

Een dergelijke reeks van 25 antwoordmogelijkheden wordt ook gegeven voor de vraag naar de gevolgde opleiding (niveau en richting). Ook deze resultaten van de loopbaanenquête zijn, zowel voor wat betreft opleidingsniveau als studierichting, terug te voeren op de Standaard Onderwijs Indeling (SOI) en derhalve inpasbaar in het ROA-informatiesysteem. Dit is eveneens mogelijk voor de (hoofd-) doktoraalvakken, zij het dat er dan een andere indeling kan ontstaan dan de indeling naar studierichting, vanwege het hiervoor al genoemde feit dat er zeer uiteenlopende afstudeervakken gekozen kunnen worden die weinig of niets met agrarische wetenschappen te maken hebben.

Voor het beroep gebruikte het MPW in 1983 een indeling die was gebaseerd op de functieomschrijvingen in de antwoorden van het loopbaanonderzoek in 1978. Zo ontstond een functie-classificatie met 15 functiegroepen. Voor het loopbaanonderzoek in 1988 is dezelfde indeling gebruikt, zij het dat de categorie 'assistent-onderzoekers en wetenschappelijk medewerkers' is gesplitst. Daarnaast vraagt het MPW ook nader naar de werkzaamheden die men uitoefent. Hiertoe is een indeling ontworpen van 16 verschillende activiteiten, zoals 'experimenteel onderzoek', 'onderwijs' of 'beheer'.

Doordat zowel de functie als de taakinhoud/werkzaamheden bekend zijn is het in principe mogelijk om een beroepenclassificatie te ontwerpen. Helaas kan 
deze voor het MPW slechts een beperkt karakter hebben omdat via de loopbaanenquête alleen de genoemde 16 categorieën bekend zijn. De door MPW gehanteerde indeling voor de functies waarin afgestudeerden werkzaam zijn is in samenhang met de door MPW onderscheiden soort activiteit (= de werkzaamheden die worden verricht in het kader van de functie) te herleiden tot de CBS Beroepenclassificatie. Het zal duidelijk zijn dat dit nogal tijdrovend en omslachtig is. Wellicht dat het NILI-ledenbestand meer mogelijkheden biedt tot categorisering volgens de CBS Beroepenclassificatie.

In de loopbaanenquête wordt ook gevraagd naar de marktsector waarin de respondent werkzaam is. Daaronder wordt verstaan: 'een voor ons onderzoek min of meer relevante en homogene groep werkgevers'. In de toelichting bij de vragenlijst zijn 52 sectoren onderscheiden. Terwille van de hanteerbaarheid voor de analyse zijn deze 52 sectoren vervolgens in 14 marktsectoren verdeeld. Deze indeling wijkt het minst af van de standaardclassificatie van het CBS, de Standaard Bedrijfs Indeling (SBI). In een aantal gevallen (met name waar het functies in het openbaar bestuur betreft) is de CBS-indeling veel te beperkt voor MPW. Zo was in 1983 van álle Wageningse afgestudeerden circa $30 \%$ werkzaam bij het openbaar bestuur. In een ander geval is de SBIindeling wel erg specifiek. Bijvoorbeeld voor diverse bedrijfssubgroepen voor handel en industrie in de voedings- en voedermiddelen industrie. Door MPW zijn deze samengevoegd tot één marktsector Voedings- en voedermiddelenindustrie en handel, onderverdeeld in 9 groepen. Deze indeling komt op geen enkele wijze met de SBI overeen, omdat in al deze groepen, twee economisch gezien verschillende bedrijfssectoren, industrie en handel, op één hoop worden gegooid.

De koppelbaarheid van de enquêteresultaten aan andere gegevensbestanden wordt ook bemoeilijkt doordat sommige omschrijvingen in de toelichtingen op de vragen naar beroep en bedrijfstak, veel ruimte laten voor verschillende interpretaties. De respondent weet dan wellicht niet goed welke mogelijkheid gekozen moet worden. Het CBS probeert deze problemen te beperken door de vragen in open vorm te stellen waarna codeurs voor de codering volgens de standaardclassificaties zorgen.

Samengevat, kan worden gesteld dat de resultaten van de vijf-jaarlijkse loopbaanenquête van de Stichting MPW in principe goed zijn te gebruiken voor het informatiesysteem voor onderwijs en arbeidsmarkt. Met name waar het 
gaat om studierichtingen die alleen in Wageningen gevolgd kunnen worden.

Indien bepaalde studierichtingen ook elders gevolgd kunnen worden, is het twijfelachtig of de MPW-resultaten alleen, een voldoende representatief beeld geven van de arbeidsmarktperspectieven van de betreffende studierichting.

Aan de andere kant lijken ook de gebruiksmogelijkheden van CBS-classificaties niet optimaal te zijn. Zo is met name de SBI-classificatie voor het 'openbaar bestuur' erg beperkt. Niet alleen omdat het voor diverse organisaties niet erg aantrekkelijk is om de SBI integraal over te nemen, maar vooral ook omdat de SBI te weinig aandacht heeft voor de omvang en verscheidenheid van de overheidssector. Om aan dit bezwaar tegemoet te komen zou in aansluiting op de SBI-indeling een meer bruikbare indeling ontworpen en gepropageerd moeten worden.

9. Relevantie van de deelmarktstudie:

Het MPW-onderzoek onder Wageningse ingenieurs levert een schat aan gegevens op over de situatie waarin afgestudeerden van één onderwijsinstelling zich bevinden. Vanzelfsprekend zijn deze gegevens vooral van belang voor de LU. Daarnaast zijn het de huidige afgestudeerden (werkenden en werkzoekenden) en studenten die geĩnformeerd worden over hun mogelijkheden op de arbeidsmarkt. Vanwege zowel het grote aantal items als het grote aantal respondenten, levert deze 5-jaarlijkse enquête eveneens interessante informatie op voor (potentiële) werkgevers. Hierbij speelt de monopoliepositie die de LU voor een aantal studierichtingen inneemt eveneens een rol. 


\section{GROOT-BRITTANNIE ALS VOORBEELD}

\subsection{Inleiding}

In de hoofdstukken 1 en 2 is uiteen gezet dat het voor een informatiesysteem onderwijs en arbeidsmarkt wenselijk zou zijn, indien aanvullende gegevensbronnen ontwikkeld zouden kunnen worden. In paragraaf 3.2 zijn de conclusies weergegeven van een inventariserend onderzoek naar de beschikbaarheid van gegevensbestanden van afgestudeerde academici, waarna in hoofdstuk 4 is ingegaan op het vijfjaarlijkse loopbaanonderzoek van de Stichting Maatschappelijke Plaats Wageningse Afgestudeerden. Voorzover bekend is de Landbouw Universiteit Wageningen de enige universiteit in ons land die met regelmaat contacten onderhoudt met haar afgestudeerden, hoewel inmiddels ook aan andere universiteiten plannen daartoe ontwikkeld worden. Het gevaar dreigt echter dat iedere universiteit er een eigen wijze van registreren en onderzoeken op na gaat houden. Het is alleen al om deze reden, nuttig om eens te bekijken hoe men in Groot-Brittannië er in slaagt om van alle 52 universiteiten en 'polytechnics', uniforme informatie over de arbeidsmarktpositie van afgestudeerden weet te verkrijgen.

In Groot-Brittannië wordt aan het eind van ieder kalenderjaar onder auspicieën van de Association of Graduate Careers Advisory Services (AGCAS) aan iedere universiteit door de Careers Advisory Service (CAS) een standaardvragenlijst voorgelegd aan álle afgestudeerden uit het voorbije academische studiejaar. De doelstelling hiervan is om aan het eind van ieder kalenderjaar een overzicht te krijgen van de vorderingen die door de afgestudeerden zijn gemaakt met betrekking tot het vinden van een werkkring of het volgen van een vervolgopleiding. In de praktijk blijken deze gegevens ook te fungeren als zogeheten 'performance indicators' van de universiteiten.

\subsubsection{De st standaardvragen 1 i j $\underline{j}$ st}

De gehanteerde standaardvragenlijst bevat in ieder geval vragen over:

1. de 'primary classification'; (de eerste bestemming van afgestudeerden na hun studie);

2. indien men werk heeft: 'employer category'; 
3. 'type of work';

4. 'location of the employer';

5. 'qualification obtained' (behaalde graad);

6. 'class of degree where appropriate' (jaar van afstuderen).

De vragen 2, 3 en 4 worden overigens alleen gesteld wanneer er sprake is van een vaste betrekking. De vorm waarin naar deze gegevens gevraagd wordt zijn open vragen, waarin gevraagd wordt naar de 'name of employer', 'location of post', 'employer's business at that location.' en 'job title'. De antwoorden op deze open vragen worden door iedere Careers Advisory Service gecodeerd volgens een classificatiesysteem dat in Bijlage III zal worden toegelicht. De op deze wijze gecodeerde en opgeslagen informatie (de antwoorden op de standaard-vragenlijst) wordt door praktisch alle universiteiten op magneetband aangeleverd aan de Universities Statistical Record (USR). Enkele kleine instellingen schrijven de gegevens overigens nog met de hand bij op de van het USR ontvangen lijsten van potentiële afstudeerders.

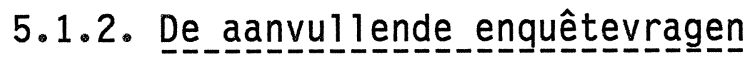

Naast deze standaardvragenlijst staat het iedere CAS of universiteit vrij om vragen toe te voegen. Een lijst met suggesties voor verdere vragen is opgenomen bij de standaard vragenlijst. Daarbij worden de volgende, niet in de standaardlijst opgenomen, items genoemd:

- Nationality;

- Country of origin (naturalised);

- County within UK;

- College/ Institute (if applicable);

- Date of award/gradution/completion/leaving;

- Sponsorship only covered under employment;

- Definition of sponsorship (may need further discussion);

- Principal source of finance;

- Professional qualifications aimed at while in employment;

- Salary (including allowances);

- Status of respondent (full-time or not);

- Age;

- Identification number;

- Teacher trainig details;

- Name of employing school; 
- Details of voluntary service, particularly overseas;

- Contact with employers (how first made);

- General survey of CAS activities;

- Offer of help and request for vacancy lists;

- Mutual aid (other services).

\subsection{Problemen bij het onderzoek}

Hoewel de AGCAS zoveel mogelijk het gebruik van een standaard vragenlijst met een beperkt aantal vragen tracht te bevorderen, teneinde uniformiteit te bereiken, doen er zich verschillende problemen voor die de vergelijkbaarheid nadelig beinvloeden. Johnes c.s. ${ }^{6}$. noemen de volgende:

1. Bij sommige universiteiten kunnen vraagtekens worden gezet bij de nauwkeurigheid van de data. ('Data are not audited')

2. Sommige universiteiten zijn meer nauwgezet bij het verzamelen van de data dan anderen. Zo zijn er opmerkelijke verschillen tussen de universiteiten in het percentage met 'onbekende bestemmingen'.

3. De methode van dataverzameling kan verschillen tussen universiteiten. Soms wordt volstaan met indirecte informatie doordat bijvoorbeeld de ouders of de afstudeervakgroep gevraagd wordt de enquête in te vullen.

4. De termijn waarbinnen de universiteiten de data verzameld hebben loopt sterk uiteen.

5. Er wordt binnen het AGCAS-onderzoek gebruik gemaakt van een eigen definitie van werkloosheid. Hierdoor doen zich problemen voor bij het vergelijken van de door het AGCAS voortgebrachte data met andere gegevensbestanden. Enkele van de ILO-standaarddefinitie afwijkende rekenwijzen zijn:

- afgestudeerden met een tijdelijke baan worden gerekend tot de werklozen: van degenen die een tijdelijke baan hebben wordt aangenomen dat zij gefaald hebben in het vinden van een permanente baan.

- afgestudeerden die niet beschikbaar zijn voor de arbeidsmarkt vanwege verdere studie worden tot werklozen gerekend.

- afgestudeerden met een onbekende bestemming worden van het totale aantal afgestudeerden afgetrokken. Universiteiten met een groot aantal niet achterhaalde afgestudeerden scoren daardoor relatief minder slecht

6. Johnes, G., J. Taylor and G. Ferguson, The employability of new graduates: a study of differences between UK universities. In: Applied Economics, 1987, 19, p. 695-710. 
met betrekking tot het percentage werklozen onder de afgestudeerden, omdat verwacht mag worden dat zich in deze categorie onbekenden relatief veel werklozen of personen met een tijdelijke baan bevinden. Hierdoor zullen universiteiten met een hoger percentage onbekenden een lager percentage werklozen meten. Dit heeft wel tot gevolg dat het werkloosheidscijfer onnauwkeuriger wordt.

Geconstateerd kan worden dat er twee belangrijke oorzaken zijn te onderscheiden voor onnauwkeurigheid en niet-optimale vergelijkbaarheid van de resultaten van de afgestudeerden, te weten: meetproblemen en definitieproblemen.

\subsection{Wat wordt er gedaan met de resultaten?}

De resultaten van de jaarlijkse enquête worden per universiteit geclassificeerd en ingevoerd op één record per afgestudeerde. De basis van ieder record is al gelegd door de University Central Council on Admissions (UCCA) de Britse tegenhanger van het Nederlandse Centraal Bureau Aanmelding en plaatsing. Deze basic information bevat geslacht, studierichting en naam, adres, woonplaats.

Al deze gegevens worden verzameld door de Universities Statistical Record (USR) die ze verwerkt tot tabellen en een aantal bewerkingen verricht. De USR lijkt ook een belangrijk aandeel te hebben in de coördinatie en kwaliteitsbewaking. De Central Services Unit (het hoofdbureau van álle aan de universiteiten verbonden Graduate Employment Services en Careers Advisory Services) verwerkt deze gegevens in allerlei publikaties voor (potentiële) studenten en werkgevers. Ook diverse ministeries en onderzoeksinstellingen maken dankbaar gebruik van de resultaten.

Voor de universiteiten, tenslotte, kunnen de gegevens eveneens van belang zijn. Dit hangt samen met de betekenis die deze 'employability index' heeft als 'performance indicator'. Deze wordt onder meer gebruikt bij de werving van nieuwe studenten, vooral door die universiteiten die erin slagen om veel 'employable graduates' te produceren. Overigens moeten dergelijke indices enigszins gerelativeerd worden vanwege de meet- en classificatieproblemen en de uiteenlopende inspanningen van de aan iedere universiteit verbonden CAS. 


\subsection{Conclusies}

Hoewel er waarschijnlijk geen enkel land is waar men zo nauwkeurig op nationale schaal kennis heeft over de eerste bestemming van academici, zijn er toch ook een aantal bezwaren aan de Britse 'first destinations surveys': - De periode tussen het moment van afstuderen en enquêteren loopt sterk uiteen. Doordat de afgestudeerden drie maanden na het beëindigen van het academisch jaar waarin ze afstudeerden een enquête toegestuurd krijgen is het mogelijk dat iemand die aan het begin van het academisch jaar afstudeert, ruim een jaar na het beëindigen van de studie een vragenlijst toegestuurd krijgt. Degenen die aan het einde van het academisch jaar afstuderen, krijgen daarentegen reeds binnen drie maanden daarna al een vragenlijst toegestuurd.

- De gehanteerde werkloosheidsdefinitie wijkt af van de internationale ILO-definitie. Hierdoor wordt de vergelijkbaarheid met andere nationaleen internationale werkloosheidscijfers onmogelijk.

- Academici worden alléén kort na hun afstuderen gevolgd. Dit is een belangrijke beperking omdat uit een onderzoek van de Careers Guidance Service blijkt dat het grootste deel van de afgestudeerden binnen 5 jaar na het voltooien van de studie één of twee keer van werkkring verandert.

- De voortgebrachte statistische gegevens worden zelden gebruikt om prognoses te maken. Wél wordt door CSU het zogenaamde data pack samengesteld. Dit is een serie statistische publicaties warop werkgevers zich kunnen abonneren. De publicaties hebben betrekking op de volgende onderwerpen: 'supply of university graduates; trends and predictions' (bevat schattingen over de uitstroom van alle universiteiten voor de komende drie jaren), 'The output of UK universities by Institutions and Disciplines' (geeft outputcijfers per instelling, studierichting, woonplaats en geslacht), 'Statistical Quarterly' (geeft up-to-date informatie over de arbeidsmarkt voor academici. Onder andere een vergelijking van de vacatureontwikkeling met het voorgaande jaar, onderzoek naar de aanvangssalarissen en de ontwikkeling van het aandeel van vrouwen in het hoger onderwijs).

Met voorgaande bezwaren zal ook in ons land rekening moeten worden gehouden indien in Nederland op een nationale schaal arbeidsmarktonderzoek zal worden verricht onder academici. 


\section{BESLUIT}

$\mathrm{Na}$ deze eerste inventarisatieronde over aanvullende arbeidsmarktgegevens voor academici kan het volgende geconcludeerd worden:

Hoewel er op diverse plaatsen (universiteiten, faculteiten, verenigingen van afgestudeerden, beroepsverenigingen, etcetera) gegevens aanwezig zijn over de arbeidsmarktpositie van academici, vormen dergelijke gegevens vooralsnog geen geschikte aanvulling van de data waarmee het informatiesysteem voor onderwijs en arbeidsmarkt momenteel wordt samengesteld. De reden daarvoor is dat geen van de aangetroffen onderzoeksresultaten of databestanden voldoet aan de door ons opgestelde criteria. Met name de vereisten van representativiteit (geven de aanvullende gegevens ook inderdaad een juist beeld van de eerste bestemming, beroep en bedrijfssector van álle afgestudeerden uit de betreffende studierichting?) en de koppelbaarheid aan andere databestanden (zijn de aanvullende gegevens ook op een dusdanige wijze gecategoriseerd dat zij "ingepast" kunnen worden in de CBS-classificaties voor opleiding, beroep en bedrijfssector ?) vormen grote struikelblokken.

Ook de andere door ons gestelde vereisten vormen waarschijnlijk een belemmering voor de gebruiksmogelijkheden. Zo is het bijvoorbeeld goed mogelijk dat de toegankelijkheid van databestanden beperkt is. Niet vanwege technische belemmmeringen maar om formeel-juridische redenen zoals statuten en privacy-reglementen. In deze inventarisatie die in de eerste plaats was gericht op de resultaten van enquêteonderzoeken en pas in tweede instantie op andere databestanden, is dit vereiste nog niet expliciet aan de orde gekomen. Met betrekking tot de vereisten van periodieke herhaling en actualiteit doet zich een verheugende tendens voor. Zowel bij universiteiten en faculteiten als bij beroepsverenigingen en verenigingen voor afgestudeerden bestaat een toenemende belangstelling voor arbeidsmarktinformatie. Om die reden wordt steeds vaker onderzoek verricht naar de arbeidsmarktpositie van afgestudeerden in de vorm van enquêtes, interviews, delphi-technieken, etcetera.

Kwantitatief vergelijkend onderzoek met bestaande databestanden heeft echter tot op heden nauwelijks plaats gevonden. Wellicht omdat de mogelijkheden hiertoe nauwelijks voorhanden zijn doordat veel onderzoeksresultaten ofwel niet te kwantificeren, ofwel niet vergelijkbaar zijn. Echter, uit diverse 
telefoongesprekken tijdens de inventarisatie is gebleken dat de belangstelling hiervoor toeneemt. Steeds vaker worden pogingen ondernomen om een beeld te krijgen van arbeidsmarktontwikkelingen. Nu de organisatorische kaders daarvoor worden opgezet is het van groot belang om tijdig een (multifunctionele) basis-vragenlijst te ontwikkelen en het gebruik daarvan te bevorderen. Daarbij zou vooral gebruik kunnen worden gemaakt van de ervaringen die in Wageningen en in Groot-Brittannië zijn opgedaan met loopbaanonderzoek onder (recent) afgestudeerden.

Door het ontwikkelen van een dergelijke standaardvragenlijst zou tegemoetgekomen kunnen worden aan de eerder genoemde tekortkoming van de slechte vergelijkbaarheid van veel tot op heden verrichtte onderzoeken. Deze vergelijkbaarheid hangt vooral af van de gehanteerde definities en de wijze van classificatie van gegevens over opleiding, beroep en bedrijfssector. De vergelijkbaarheid wordt zoals gezegd veelal onmogelijk gemaakt doordat wordt afgeweken van standaarddefinities en standaardclassificaties. In plaats daarvan wordt volgens eigen inzichten inhoud gegeven aan begrippen als werkloosheid en werkgelegenheid. Misschien vormen onbekendheid met de standaarddefinities en -classificaties, onvermogen of het ontbreken van enig belang een reden om deze niet te gebruiken. Ook is het denkbaar dat deze classificaties in sommige gevallen te diepgaand zijn voor eigen gebruik.

Het ROA zal zich dan ook in de naaste toekomst bezig gaan houden met het ontwikkelen en bekend maken van een standaardvragenlijst zoals dat in GrootBrittannië door het AGCAS wordt gedaan. Bij deze standaardvragenlijst zal gebruik worden gemaakt van de standaarddefinities en -classificaties. Tevens zal met de belangrijkste van de in deze inventarisatie genoemde (intermediaire-) organisaties contact op worden genomen om te bezien welke vereisten in het veld worden gesteld aan een dergelijke standaardvragenlijst. Ook instellingen als de VSNU, het CBS en het Ministerie van Onderwijs en Wetenschappen zal om advies worden gevraagd. Bovendien zal de inventarisatie van aanvullende gegevensbronnen over de arbeidsmarktpositie van afgestudeerden worden uitgebreid tot het Hoger Beroeps Onderwijs. 


\author{
BIJLAGE I : OVERZICHT VAN DEELMARKTSTUDIES EN DATABESTANDEN \\ BIJLAGE II : DEFINITIES EN CLASSIFICATIES MPW-ONDERZOEK \\ BIJLAGE III : DEFINITIES EN CLASSIFICATIES AGCAS (GROOT BRITTANNIE) \\ BIJLAGE IV : PUBLICATIE-OVERZICHT VAN GEINVENTARISEERDE DEELMARKTSTUDIES
}


BIJLAGE I: Overzicht van deelmarktstudies en databestanden

In deze Bijlage wordt dieper ingegaan op de enquêtes en databestanden van faculteiten en vakgroepen, en van beroepsverenigingen en verenigingen van afgestudeerden. Deze worden besproken aan de hand van de in paragraaf 3.2 genoemde aandachtspunten'.

- van welke organisatie zijn de gegevens afkomstig?

- door wie zijn ze bijeengebracht? Wanneer?

- om welke onderzoekspopulatie gaat het?

- is er sprake van een representatief onderzoek?

- welke dekkingsgraad is bereikt en op welke wijze is het contact met de onderzoekspopulatie onderhouden of tot stand gekomen?

- wat was de doelstelling van het onderzoek?

- gehanteerde onderzoeksmethode?

- wat waren de belangrijkse onderzoeksvragen en -items?

- welke definities en classificaties voor beroepen en bedrijfstakken zijn gehanteerd en zijn er mogelijkheden om deze te vertalen naar CBS-classificaties?

- zijn de resultaten bruikbaar voor het informatiesysteem?

\section{ACADEMICI (Algemeen)}

Het meest omvangrijke adressenbestand van afgestudeerde academici is bekend bij Intermediair. Daarbij weet men ook de studierichting, functie- en werkgeverscategorie. Hoewel deze laatste twee soorten gegevens op een gehee 1 eigen wijze zijn geclassificeerd waardoor ze niet koppelbaar lijken te zijn aan CBS-classificaties, is het toch de moeite waard om contact op te nemen met Intermediair. Immers, het gaat om een groot aantal waarnemingen die op een zeer verfijnde wijze zijn geclassificeerd.

\section{LETTEREN}

Nederlands

RUU; Faculteit Letteren, vakgroep Neerlandistiek;

Verricht door: faculteitsmedewerker, in: 1986.

Onderzoekspopulatie: álle afgestudeerden Nederlands van genoemde vakgroep gedurende periode 1 januari 1978 - 1 januari 1986.

Representativiteit: van de 346 afgestudeerden zijn er 343 bereikt.

Contact onderhouden door: geen.

7. Dit overzicht heeft niet de pretentie volledig te zijn, gezien de hoge frequentie waarmee de laatste paar jaar talloze ad hoc initiatieven zijn ontwikkeld om een onderzoek op te zetten onder afgestudeerden. Gesteld mag worden dat in ieder geval de belangrijkste de laatste jaren in ons land gehouden onderzoek onder afgestudeerde academici in ons overzicht zijn betrokken. 
Doelstelling: waar zijn afgestudeerde neerlandici terecht gekomen?

Onderzoeksmethode: mondelinge- of schriftelijke benadering, zonder vragenlijst, van alle afgestudeerden die te achterhalen waren.

Onderzoeksvragen: jaar van afstuderen, afstudeerrichting, uitgeoefende (hoofd)-activiteit op het contactmoment.

Definities en classificaties: geen classificatie gebruikt.

Conclusie: resultaten niet bruikbaar voor informatiesysteem.

Andere talen: geen deelmarktstudies bekend.

THEOLOGIE:

Geen deelmarktstudies bekend.

AGRARISCHE WETENSCHAPPEN EN HUISHOUDKUNDE:

Verwezen wordt naar het NILI/MPW-onderzoek onder afgestudeerden van de Landbouw Universiteit Wageningen dat uitgebreid is besproken in hoofdstuk 4 en Bijlage II.

WIS- en NATUURKUNDE:

Van faculteiten of vakgroepen zijn geen studies bekend.

Van beroepsverenigingen is het volgende bekend:

Natuurkundigen:

Nederlandse Natuurkundige Vereniging (NNV): Commissie Werkgelegenheid voor Fysici. In: 1983.

Onderzoek verricht door: medewerker van genoemde Commissie.

Onderzoekspopulatie: álle (6878) Natuurkundigen die tussen 1950 en 1984 in Nederland zijn afgestudeerd in de experimentele-, theoretische- of technische natuurkunde.

Representativiteit: van álle afgestudeerden zijn gegevens bekend.

Contact onderhouden door: permanente gegevensverzameling door administraties van alle Nederlandse (sub)faculteiten Natuurkunde en de secretariaten van de beroepsverenigingen.

Doelstelling: hoe is de werkgelegenheid van natuurkundigen?

Onderzoeksmethode: analyse van bestaande databestand. 
Onderzoeksvragen en -items: huidige (arbeids)situatie: (overleden, gepensioneerd, werkzaam), leeftijd, gepro- moveerd, sector waarin men werkzaam is, vertrek naar het buitenland.

Definities en classificaties: er worden vier werkgeverssectoren onderscheiden.

Conclusie: de wijze waarop de gegevens thans gepresenteerd worden is niet bruikbaar voor het informatiesysteem. Daar van álle natuurkundigen in ieder geval het huidige beroep bekend is, is gedeeltelijke classificatie mogelijk zij het zeer bewerkelijk (circa 6000 personen).

De Nederlandse Natuurkundige Vereniging (NNV) heeft naar schatting 3500 (student-) leden. Van de leden is jaar en plaats van afstuderen bekend. De functie op het moment van abonneren is doorgaans ook bekend.

\section{Biofysici:}

Koninklijke Nederlandse Akademie van Wetenschappen (KNAW), Commissie voor de Biochemie en de Biofysica.

Door: medewerkers van genoemde Commissie, In: 1986.

Onderzoekspopulatie: álle biofysici in Nederland tot en met eind 1984. Onder biofysici worden degenen verstaan die in één van de exacte wetenschappen zijn afgestudeerd en zich een aantal jaren hebben bezig gehouden met de fysische benadering van levensprocessen.

Representativiteit: uiteindelijk bleken 1331 personen van mening te zijn aan bovengenoemde criteria te voldoen. Onbekend is om welk deel van de totale populatie het gaat omdat de precieze omvang daarvan onbekend is.

Contact gelegd door: onbekend (niet in rapport vermeldt).

Doelstelling: wat is opleiding en bestemming van biofysici?

Onderzoeksmethode: onbekend.

Onderzoeksvragen en -items:

- geslacht;

- jaar van aankomst, van kandidaatsexamen en van doctoraal/ingenieursexamen en van promotie;

- hoofdrichting binnen de verschillende examens;

- (eerste) bestemming van de biofysici na afstuderen en promotie;

Definities en classificaties: alleen voor 'eerste bestemming' worden enkele globale categorieën onderscheiden.

Conclusie: gegevens in huidige vorm niet bruikbaar voor het informatiesysteem. Nagegaan zou moeten worden wat de basis is van het genoemde rapport, welke gegevens precies aanwezig zijn en in welke vorm. 
Biochemici:

Koninklijke Nederlandse Akademie van Wetenschappen, Commissie voor de biochemie en de biofysica.

Door: twee medewerkers van genoemde Commissie, In: 1986.

Onderzoekspopulatie: de in 1984 en 1985 afgestudeerden of gepromoveerden in de biochemie.

Representativiteit: Onbekend. In de genoemde periode zijn van 226 afgestudeerde biochemici de gegevens bekend.

Contact onderhouden door: onbekend

Doelstelling: hoe heeft de arbeidsmarkt voor biochemici zich in 1984 en 1985 ontwikkeld?

Onderzoeksmethode: onbekend

Onderzoeksvragen: in ieder geval is bekend: universiteit en jaar van afstuderen, promotie, jaar van promotie, eerste bestemming na afstuderen of promoveren, wel of niet als werkzoekend ingeschreven.

Definities en classificaties: identiek als bij biofysici.

Conclusie: resultaten in huidige vorm niet bruikbaar voor het informatiesysteem. Onbekend is op wélke wijze, wélke gegevens zijn verkregen en in welke vorm zij aanwezig zijn. De antwoorden hierop zijn bepalend voor de uiteindelijke bruikbaarheid.

\section{Biologen:}

Geen onderzoeken verricht door faculteiten of vakgroepen.

Wel is er een onderzoek van de beroepsvereniging bekend.

Onderzoek verricht door: Nederlands Instituut van Biologen, In: 1983.

Onderzoekspopulatie: álle afgestudeerden van (sub)faculteiten Biologie in de periode september 1977 - augustus 1983.

Wijze waarop contact is gelegd: schriftelijke enquête naar laatst bekende adres bij subfaculteit of naar adres ouders indien onzeker was dat ze daar nog woonden.

Representativiteit: Gedurende de genoemde studiejaren studeerden volgens CBS cijfers 3200 biologen af. De enquête is aan 2997 personen verzonden, $5 \%$ kwam als onbestelbaar terug. De respons bleek uiteindelijk $50.7 \%$ te zijn.

Doelstelling: vanwege werkloosheid onder afgestudeerde biologen, een zo volledig mogelijk beeld te krijgen van de arbeidsmarktsituatie voor biologen.

Onderzoeksmethode: schriftelijke enquête met 80 vragen met voornamelijk 
gesloten antwoordcategorieën.

Onderzoeksvragen en items:

- persoonskenmerken;

- opleidingskenmerken: (universiteit, afstudeerjaar, studieduur, promotie, doktoraalvakken, waar zijn de diverse doktoraalvakken behaald, tot welk soort bioloog rekent men zich, nevenaktiviteiten, extra opleidingen, gemiste aspecten in de opleiding, (PAO-)wensen);

- functie- en carriére-kenmerken: (aard van de bezigheden (10) ${ }^{8}$, inhoud van het werk $(60)$, in welke sector valt uw werk (6), bij welke instantie werkt $u$ (open), aard van de betrekking (5), andere functies na afstuderen);

- indien zonder inkomen uit arbeid: (effect van overheidsinstituten en

- maatregelen, andere activiteiten, wijze van werk zoeken en vinden, aard van het gezochte werk);

- mening over werkloosheid onder biologen;

Gehanteerde definities en classificaties:

Werkgelegenheid: percentage met een betaalde betrekking.

Classificaties:

Lijst van vakgroepen en instituten (letter-cijfer code)

Lijst van vakgebieden en afstudeeronderwerpen;

Sector waarin men werkzaam is: zes mogelijkheden.

Conclusie: resultaten nauwelijks bruikbaar voor het informatiesysteem.

\section{Scheikundigen/ chemici:}

De Koninklijke Nederlandse Chemische Vereniging (KNCV) houdt iedere twee jaar een vacature-prognose enquête onder bedrijven met chemici in dienst. Vorig jaar is voor het eerst sinds 8 jaar weer een enquête onder de leden ( 11.000 waarvan circa 7.000 academici) gehouden. In deze enquête, waarvan het verslag nog niet is afgerond, is niet gevraagd naar functie/beroep zodat de gebruiksmogelijkheden beperkt lijken te zijn.

\section{TECHNISCHE WETENSCHAPPEN:}

Geen onderzoeken van (technische) universiteiten, faculteiten of vakgroepen bekend.

Wél heeft het Koninklijk Instituut van Ingenieurs (KIVI) een omvangrijk leden- en adressenbestand, onderverdeeld in diverse afdelingen bijvoorbeeld Bedrijfskunde, Bouwkunde etcetera. Het KIVI heeft naar schatting 18.000 leden waarvan er 12.000 werkzaam zijn (Overigen zijn studentleden of senior-leden). De totale populatie van technisch ingenieurs in Nederland is naar schatting 42.000. Bij het KIVI denkt men (eventueel)

8. Tussen haakjes het aantal keuzemogelijkheden. 
aan een uitgebreidere wijze van ledenregistratie maar een geschikt registratiesysteem ontbreekt tot op heden.

\section{MEDISCHE OPLEIDINGEN:}

Medicijnen: geen onderzoek van faculteiten bekend; wél hebben verschillende beroepsverenigingen en instanties cijfers over medische beroepsgroepen.

Tandheelkunde: geen onderzoek van faculteiten bekend; idem.

Diergeneeskunde: zeer recent is een arbeidsmarktonderzoek onder veterinair opgeleiden (RUU) afgerond. Opdrachtgevers voor dit onderzoek waren zowel de faculteit diergeneeskunde als de beroepsvereniging KNMD. Het onderzoek is uitgevoerd door ITS Nijmegen. De onderzoeksresultaten zijn nog niet openbaar.

Tevens zijn bij de Koninklijke Nederlandse Maatschappij voor Diergeneeskunde gegevens bekend over álle in Nederland opgeleide en werkzame dierenartsen.

\section{GEZONDHEIDSWETENSCHAPPEN :}

RL: Faculteit Gezondheidswetenschappen.

Verricht door: twee faculteitsmedewerksters, in 1988.

Onderzoekspopulatie: alle 273 gezondheidswetenschappers die tot mei 1987 zijn afgestudeerd.

Representativiteit: 183 van de 273 afgestudeerden hebben een toegezonden vragenlijst ingevuld en geretourneerd.

Contact onderhouden door: adressenbestand van de vereniging van afgestudeerden.

Doelstelling: tweeledig:

1. Waar komen afgestudeerde gezondheidswetenschappers in het beroepsveld terecht?

2. Aan welke voorwaarden moet worden voldaan bij de ontwikkeling van meetinstrumenten, een continue evaluatie en follow-up onderzoek onder gezondheidswetenschappers?

Onderzoeksmethode: schriftelijke enquête.

Onderzoeksvragen en -items:

1. Algemene kenmerken;

2. Vragen voor niet-werkenden;

3. Vragen voor werkenden:

4. Slotvragen.

Definities en classificaties:

Werkgelegenheid/ werkloosheid: onderscheidend criterium hiervoor is het al dan niet 'verrichten van betaalde arbeid'. Met andere woorden: vee 1 wordt overgelaten aan de interpretatie van de respondent. Bijvoorbeeld 
of free-lance werkzaamheden, militaire dienst of het werken met een (aanvullende) uitkering hier ook onder vallen.

Soort organisatie waar men werkzaam is: hier wordt een reeks van organisaties gegeven die enerzijds veel overlappende categorieën bevat, anderzijds weinig onderscheid geeft. Categorieën zijn bijvoorbeeld 'Bedrijfsleven', 'overheid', 'financiële instellingen' etcetera.

Conclusie: resultaten lijken in eerste instantie nauwelijks bruikbaar te zijn als gevolg van de gekozen classificaties. Echter, de vragenlijst bevat open vragen voor de instelling of organisatie waar men werkzaam is, de officiële functiebenaming en de belangrijkste taken. Aan de hand van het basismateriaal (de ingevulde vragenlijsten) is classificatie volgens CBS-indelingen mogelijk, waarna opname in het informatiesysteem mogelijk is.

\section{FARMACOLOGIE:}

Geen onderzoeken van faculteit of vakgroep bekend.

Bij de Koninklijk Nederlandse Maatschappij voor Pharmacie is wel bekend wélke personen zijn afgestudeerd in de farmacie en een apothekersopleiding hebben afgerond. Tevens is van deze personen (indien zij werkzaam zijn als apotheker) bekend of zij als zelfstandige of bij een bedrijf of instelling werkzaam zijn.

ECONOMISCHE WETENSCHAPPEN EN BEDRIJFSKUNDE (drs.):

Ook van de Economische faculteiten zijn geen onderzoeken bekend onder afgestudeerden. Veel faculteiten laten dit over aan de Verenigingen van afgestudeerden, die op hun beurt verenigd zijn in de Stichting Landelijke Samenwerking Economisten (LSE). De adresregistratie voor alle hierbij aangesloten verenigingen is ondergebracht bij de Stichting Adreslijst Economisten. Deze Stichting beschikt over circa 10.000 adressen van doctorandi in de economie met een abonnement hebben op het gratis economenblad. Dit is naar schatting tweederde van de totale populatie doctorandi in de economie.

Recentelijk is onder deze abonnees een enquête gehouden. De respons hierop bedroeg naar schatting $23 \%$ In deze enquête kwam een groot aantal items aan de orde. Voor de indeling van functies en werkgevers is gebruik gemaakt van de CBS-classificaties. De resultaten van deze enquête worden nog geanalyseerd.

Ook de faculteiten voor Bedrijfskunde aan de RUG, EUR en Nijenrode kennen verenigingen van afgestudeerden. Met een lijst met daarin adres, functie en sector waarin men werkzaam is (RUG, met vereniging BRUG) of een almanak (EUR, interfaculteit met TUD met vereniging VIB en Nijenrode) met daarin werkgever en functie (ongecodeerd).

\section{ECONOMETRIE, ACTUARIAAT EN BEDRIJFSKUNDE (ir.):}

Geen onderzoeken van faculteit of vakgroep bekend. 
Wel heeft de vakgroep Econometrie van de KUB de Vereniging van Afgestudeerde Econometristen. Van nagenoeg alle sedert 1952 afgestudeerden (uitgezonderd de 78 niet-leden) zijn zowel functie als werkgever bekend, zodat indeling volgens de standaard-classificaties mogelijk is. (De VAET heeft ook een eigen indeling in 22 branches en 13 functiecategorieën).

Conclusie: deze gegevens zijn, na bewerking, goed bruikbaar voor een informatiesysteem onderwijs-arbeidsmarkt. Met name vanwege het permanente karakter van de gegevensregistratie. Wel moet bedacht worden dat het nog geen representatief beeld geeft van alle afgestudeerden in de econometrie.

Ook de andere econometrie-faculteiten in den lande (UVA, VU, EUR Groningen) hebben verenigingen van afgestudeerden. Niet bekend is op welke wijze zij de gegevens registreren.

\section{Bedrijfskunde aan Technische Universiteiten:}

Beide faculteiten Bedrijfskunde aan een technische universiteit (UT en TUE) hebben een vereniging van afgestudeerden (respectievelijk BeKader en VBI). Van BeKader is bekend dat circa $70 \%$ van de afgestudeerden ( 350 personen) lid is. Ieder jaar wordt een almanak uitgegeven met daarin van alle leden gegevens over onder andere werkgever, branche en functie. Deze gegevens zijn op dezelfde wijze gerubriceerd als Intermediair dat doet met haar abonnees. Deze gegevens worden jaarlijks, vóór uitgave van de almanak, gecontroleerd op juistheid.

\section{RECHTEN:}

1. EUR: Faculteit Rechtsgeleerdheid.

Onderzoek verricht door: Bureau Onderwijszaken van de Faculteit, maart 1987 en april 1988. Voornemen om dit jaarlijks te doen, zowel voor pasafgestudeerden als voor degenen die circa drie jaar geleden zijn afgestudeerd.

Onderzoekspopulatie: álle afgestudeerden in het kalenderjaar 1986 die tenminste drie jaren als voltijdstudent ingeschreven hebben gestaan en die beschikbaar zijn voor de arbeidsmarkt. Zij die bijvoorbeeld de dienstplicht vervullen of met een vervolgstudie bezig zijn, kwamen derhalve niet in aanmerking.

Wijze waarop contact is gelegd: schriftelijke enquête naar studieadres direkt ná afstuderen (met rappéls 2, 6 en 12 maanden na afstuderen indien nog geen reaktie), met port-vrije retour-enveloppe.

Representativiteit: van de 253 benaderde studenten hebben er 245 gereageerd (97\%). Om eerder vermelde redenen zijn 47 afgestudeerden buiten het onderzoek gehouden, zodat 198 respondenten overbleven.

Doelstelling: kwaliteitsbewaking van het onderwijs aan de faculteit, inzicht in arbeidsmarktperspectieven van afgestudeerden, inzicht in de eisen vàn en de ontwikkelingen òp de arbeidsmarkt voor juristen.

Onderzoeksmethode: schriftelijke enquête. 
Onderzoeksvragen en -items:

- wel/niet afgestudeerd;

- geslacht;

- wel/geen werk gevonden: indien wel: indeling over sectoren van de arbeidsmarkt: 5 hoofdgroepen, 18 groepen en 4 subgroepen;

- termijn waarbinnen werk is gevonden;

- studieduur;

- leeftijd bij afstuderen;

- gevolgde afstudeervariant (6 mogelijkheden);

- functiebenamingen en -omschrijvingen (open);

- voor werkenden: regio van tewerkstelling;

Gehanteerde definities en classificaties:

Werk: niet nader gespecificeerd voor pro-deo, tijdelijke of vaste betrekking. Dienstplichtig militairen, afgestudeerden bezig met een vervolgopleiding en werkzoekenden worden hier niet toe gerekend.

Bedrijfssector: onderverdeling in 21 categorieën. Komt overeen met Standaard Bedrijfs Indeling tot op 2 digit. Sectoren Overheid, Onderwijs en Typisch Juridische Sector zijn gespecificeerd op 4 digitniveau. De sectoren Bedrijfsleven en Diensten zijn echter niet verder te gespecificeerd.

Functiebenamingen en -omschrijvingen: de hier verkregen reeks zijn de antwoorden op een open vraag. Aldus is op basis van deze antwoorden een functie-classificatie ontstaan van inmiddels 75 functies. Het ordeningscriterium daarbij was in het eerste jaar alfabetische volgorde. De in 1986 toegevoegde functies hebben een willekeurige cijfercode gekregen.

Studierichting: van de respondenten is bekend welke van de zes mogelijke afstudeervarianten zij gevolgd hebben. Aansluiting bij SOI is mogelijk.

Conclusie: Enquêteresultaten zijn in de vorm waarin zij thans gepresenteerd worden nauwelijks bruikbaar voor een informatiesysteem. Na (her)codering van de basis-gegevens lijken ze echter goed bruikbaar.

\section{RL: Faculteit Rechten:}

Onderzoek verricht door: twee hoogleraren i.0.v. Stichting Jurist en Werk. In: mei 1988.

Onderzoekspopulatie: álle tussen 1 juni 1985 en 1 feb. 1988 afgestudeerde juristen van RUG (800), RUL (1425) en RL (183).

Wijze waarop contact is gelegd: via studie-adres of: indien nonrespons, via adres ouders.

Representativiteit: respons RUG en RUL: $40 \%$, respons RL: $55 \%$.

Doelstelling: wat zijn de arbeidsmarktperspectieven van juristen, gezien de grote hoeveelheid jonge juristen die momenteel de arbeidsmarkt betreden? 
Onderzoeksmethode: schriftelijke enquête.

Onderzoeksvragen en -items:

- persoonsgegevens;

- vooropleiding, werkervaring, nevenactiviteiten en studie;

- werk: (60 zeer uiteenlopende items);

Gehanteerde definities en classificaties:

Betaalde baan: niet nader gedefinieerd. (Wel nauwkeuriger te interpreteren door aanvullende vragen).

Opleiding en afstudeerrichting: bekend. SOI mogelijk.

Voor functie/beroep is een open vraag opgenomen: codering gebeurt bij het invoeren.

Voor de bedrijfssector waarin men werkzaam is, kan uit een reeks sectoren gekozen worden die is gebaseerd op de SBI.

Conclusie: De bruikbaarheid is in dit geval vooral afhankelijk van de vraag of de onderzoeksresultaten een voldoende representatief beeld geven van de rechtenstudie. De resultaten lijken wat classificaties betreft zeer goed in te passen in het informatiesysteem.

SOCIAAL-CULTURELE WETENSCHAPPEN:

\section{Politicologen:}

UvA; Politicologie, Sub-Faculteit Algemene Politieke en Sociale Wetenschappen, (FSW-A).

Onderzoek verricht door: studiecoördinator in 1982.

Onderzoekspopulatie: 250 volgens het Onderwijsprogramma 1971 afgestudeerde politicologen in de periode 1 januari 1975 - 1 januari 1982.

Wijze waarop contact is gelegd: schriftelijke enquête voorzover het woonadres nog te achterhalen was.

Representativiteit: van de 250 afgestudeerden in die periode, was van 244 het adres nog te achterhalen. Van de 244 verzonden vragenlijsten zijn er $170(=70 \%)$ op een bruikbare wijze ingevuld en geretourneerd.

Doelstelling: in welk soort functies en in welke sectoren komen afgestudeerde politicologen terecht?

Onderzoeksmethode: schriftelijke enquête.

Onderzoeksvragen en -items:

- eerste bestemming na het afstuderen;

- werkkring waar men terecht is gekomen; 
- werkkring naar afstudeerrichting;

- functie waarin men werkzaam is;

- studie-evaluatie;

- nascholing;

Gehanteerde definities en classificaties:

Werklozen: degenen die opgeven geen werkkring te hebben en niet in militaire dienst zitten, huisvrouw zijn of een vervolgopleiding volgen. Classificaties: Bedrijfssector: 13 categorieën (voornamelijk onderscheid in overheid en onderwijs), soort functie: 12 categorieën. Indeling voor functiesoort is te herleiden tot Beroepenclassificatie tot 2 digit-niveau.

Conclusie: hoewel de resultaten van het onderzoek op zich goed bruikbaar zijn, betreft het een beperkt deel van de totale populatie. Hierdoor zijn de gebruiksmogelijkheden voor het informatiesysteem beperkt.

\section{Sociologen:}

RUG; Faculteit Sociologie

Onderzoek verricht door: hoogleraar Sociologisch Instituut RUG in het kader van het sedert 1968 lopende TFS-onderzoek (Taak en functie van sociologen). NB.: In 1985 (voorlopig) stopgezet vanwege pensionering hoogleraar (prof. IJzerman).

Onderzoekspopulatie: alle in Nederland afgestudeerden in de westerse sociologie in de periode 1978-juni 1981.

Wijze waarop contact is gelegd: schriftelijke vragenlijst die vier maanden na het afstuderen werd verzonden naar adressen van afgestudeerden die van de deelnemende universiteiten werden verkregen.

Representativiteit: uit vergelijking met CBS-cijfers over het aantal afgestudeerden bleek dat $17 \%$ van de adressen ontbrak. Van degenen van wie een adres was verkregen zonden 471 (73\%) de vragenlijst ingevuld terug. Het totale aantal respondenten in het zogeheten TFS-onderzoek was 3155.

Doelstelling: in kaart brengen van beroepsperspectieven van afgestudeerde sociologen in Nederland.

Onderzoeksvragen en -items:

- personalia;

- aard van de werkkring:

- maatschappelijke sector waarin men werkzaam is;

- functie (incl. opleidings- en ervaringseisen);

- belangrijkste taken;

- sollicitatie-aspecten;

Gehanteerde definities en classificaties:

Aard van de werkkring: alleen onderscheid in full-time, part-time of zonder werkkring. Onbekend is of een nadere aanduiding bekend is. 
Maatschappelijke sector: 6 sectoren worden onderscheiden, bijvoorbeeld 'overheid', 'onderzoek' en 'ondernemingen'.

Belangrijkste taak: 6 soorten taken worden onderscheiden, bijvoorbeeld 'onderzoek', 'onderwijs', 'advisering' of 'management'.

Conclusie: het opgebouwde gegevensbestand lijkt om een aantal redenen aantrekkelijk: met name vanwege de omvang, 'dekking' en de lange tijd waarover gegevens zijn verzameld. Niet duidelijk is in welke basisvorm de data beschikbaar zijn: de hiervoor genoemde indelingen zijn (te) globaal om zinvol in een informatiesysteem te worden opgenomen.

\section{Sociologen en antropologen:}

De Nederlandse Sociologische en Antropologische Vereniging (NSAV) heeft circa 7.000 leden. In het begin van dit jaar is een vragenlijst verzonden naar circa 1380 van deze leden. Daarvan is inmiddels $70 \%$ geretourneerd. Zowel voor functie/beroep als voor opleiding en bedrijfstak is een standaard CBS-indeling gebruikt, zodat de voortgebrachte gegevens zeer goed te gebruiken lijken voor het informatiesysteem. In januari 1989 wordt het eerste verslag verwacht. Het voornemen bestaat om regelmatig (om de drie, vier jaar) een loopbaanonderzoek te houden onder de leden. Contactpersoon: dr. J. Dronkers, Katholieke Universiteit Tilburg.

\section{Psychologen:}

RUG: Faculteit Psychologie, vakgroep Klinische Psychologie.

Onderzoek verricht door: medewerker vakgroep in 1987. (Schaufe1i, 1987)

Onderzoekspopulatie: de 161 tussen 1 januari 1983 en 31 december 1986 afgestudeerde Klinisch Psychologen van de RUG.

Contact gelegd door: schriftelijke enquête gestuurd naar laatst bekende studie-adres. Van een aantal als onbestelbaar geretourneerden werden via arbeidsbureau, informele contacten en de burgerlijke stand van enkele gemeenten de actuele adressen verkregen.

Representativiteit: uiteindelijk werden 120 ingevulde vragenlijsten ontvangen. Respons: $75 \%$

Doelstelling: zijn de officiële werkloosheidscijfers van SoZaWe over klinisch psychologen juist? Meer algemeen was de doelstelling om de arbeidsmarktpositie van afgestudeerden in kaart te brengen.

Onderzoeksvragen en -items:

- personalia;

- aard van de werkkring;

- wijze waarop baan is verkregen;

- aard van de werkzaamheden;

- soort instelling;

- evaluatie onderwijs;

- behoefte aan nascholing; 
Gehanteerde definities en classificaties:

Werkgelegenheid: het onderscheidende criterium hiervoor is het al dan niet hebben van betaald werk.

Geen classificaties (open vragen). Bij de verwerking gehanteerde indelingen:

Werkterrein: 5 categorieën

Aard van werkzaamheden: 5 categorieën.

Conclusie: de bij de verwerking gehanteerde indelingen zijn onbruikbaar voor een informatiesysteem. Omdat het antwoorden op open vragen betreft is eigen classificatie en opname in principe mogelijk.

UvA: Vakgroep Klinische Psychologie

Onderzoek verricht door: medewerkers vakgroep in 1986. (Dijkstra en Bannenberg, 1986).

Onderzoekspopulatie: 122 recentelijk aan de UvA afgestudeerde klinisch psychologen. (nov.'82 - nov.' 85 ).

Wijze waarop contact is gelegd: telefonische benadering van afgestudeerden. Ook achterhalen van huidige adres door middel van telefonische recherche.

Representativiteit: 113 van de 122 afgestudeerden werden achterhaald: $93 \%$.

Doelstelling: waar zijn pas-afgestudeerde klinisch psychologen terecht gekomen?

Onderzoeksmethode: ongestruktureerde, telefonische enquête.

Onderzoeksvragen en -items:

- heeft men werk gevonden?

- inhoud van het werk;

- wijze waarop men aan dat werk is gekomen;

- tevredenheid van de werkenden;

- zou men opnieuw voor de studie gekozen hebben;

- studieschulden;

- huwelijkse staat

Gehanteerde definities en classificaties: geen

Conclusie: resultaten niet bruikbaar voor informatiesysteem vanwege ongestruktureerde wijze van gegevensverzameling en ontbreken van onderscheid tussen functie-omschrijving, taak-omschrijving en arbeidssector.

\section{RUL; vakgroep Klinische Psychologie}

Onderzoek verricht door: medewerkers vakgroep in 1986. (Kerkhof en Engels, 1986)

Onderzoekspopulatie: afgestudeerde $k l i n i s c h$ psychologen in de periode 
september 1983 en september 1986.

Wijze waarop contact is gelegd: in eerste instantie schriftelijke benadering, vervolgens werd getracht de non-respons groep via telefonische recherche te verkleinen.

Representativiteit: van $91(90 \%)$ van de 101 in deze periode afgestudeerden is ofwel schriftelijk ofwel telefonisch informatie verzameld.

Doelstelling: verkennen van werkgelegenheidsperspectieven.

Onderzoeksvragen en -items:

- verrichten van (betaalde) werkzaamheden;

- wel/geen psychologische werkzaamheden;

- plaats en aard van de werkzaamheden;

- wijze waarop men aan een baan is gekomen;

- werklozen;

- werkzoekenden;

- neven-werkzaamheden en onbetaalde arbeid.

Conclusie: de resultaten van deze enquête zijn enigszins bruikbaar voor het informatiesysteem onderwijs-arbeidsmarkt hoewel het onderscheidend criterium voor werkgelegenheid nogal vaag is (het hebben van betaald werk). Wel is het zo dat de 'plaats en aard van de werkzaamheden' van de afgestudeerden dusdanig specifiek is dat zij zijn te herleiden tot voor het informatiesysteem bruikbare indelingen. 
BIJLAGE II: Definities en classificaties MPW-onderzoek

Door de Stichting Maatschappelijke Plaats Wageningse Afgestudeerden gehanteerde onderzoeksitems, definities en classificaties:

\section{Onderzoeksitems:}

In de vragenlijst voor de loopbaanenquête van 1983 kwamen de volgende items aan de orde:

- persoonlijke gegevens;

- opleiding;

- kenmerken van de functie

- aansluiting van de functie op de opleiding

- mobiliteit;

- concurrentiepositie;

- onbetaald werk;

- buitenlandse werkervaring;

- plannen voor zelfstandige vestiging;

- wensen ten aanzien van PAO-cursussen en taalonderwijs.

In de loopbaanenquête van 1988 werden daaraan de volgende items toegevoegd:

- leeftijd;

- studieduur;

- laatstgenoten vooropleiding (voor LU);

- indien werkloos: reden werkloosheid;

- bruto jaarinkomen;

- opleiding die het beste aansluit op huidige functie;

- praktijkervaring van belang voor het verkrijgen van de huidige functie?

- evaluatie studiel onderwijs.

\section{Definities:}

In de MPW-enquête worden de volgende definities gehanteerd:

- Functie: elk pakket van beroepsmatig uitgeoefende taken waarmee geld wordt verdiend. Free-lance werk dient te worden gezien als één functie, NIET als een reeks van afzonderlijke functies. Het gaat alléen om betaalde functies. Militaire dienst of vervangende dienstplicht worden niet als een functie aangemerkt. Indien meerdere functies tegelijkertijd werden vervuld dient alleen de voor respondent belangrijkste functie te worden beschouwd.

- Vaste functie: een functie aangegaan voor een onbepaalde tijd, behoudens een proefperiode.

- Tijdelijke functie: een functie aangegaan voor een in het arbeidscontract omschreven tijdsduur van bv. 6 maanden, 2 jaar en dergelijke. 
- Pro deo werk: hieronder wordt niet verstaan: beroep van huisvrouw, in het bedrijf meewerkende echtgeno(o)t(e) of onbetaald verenigings-, buurt- en clubhui swerk.

\section{Indelingen:}

In de vragenlijst voor de loopbaanenquête voor 1983 werden de volgende indelingen gebruikt:

- voor Arbeidssituatie:

0 . Nog niet afgestudeerd;

1. Betaalde functie (loondienst);

2. Zelfstandig, eigen bedrijf, free-lance;

3. Combinatie loondienst-eigen bedrijf;

4. Geen betaalde functie - niet werkzoekend;

5. Geen betaalde functie - wel werkzoekend;

6. Dagstudie (na afstuderen LH) - NIET werkzoekend;

7. Dagstudie (na afstuderen LH) - WEL werkzoekend;

8. Militaire dienstplicht;

9. Gepensioneerd/VUT/arbeidsongeschikt;

- voor Opleiding:

Blijkens de toelichting op de vragenlijst zijn er (in de loop der jaren) circa 40 mogelijke studierichtingen (geweest), met in 1983103 verschillende differentiaties en 125 verschillende (hoofd-)doktoraalvakken. (In Wageningen wordt bv. ook kunstgeschiedenis als doktoraalvak gegeven. Vraag: kan Kunstgeschiedenis ook als hoofd-doktoraalvak gevolgd worden zodat iemand in feite afgestudeerd is in de agrarische kunstgeschiedenis? Idem voor Wiskunde, Wegen Waterbouwkunde, Natuurkunde, Wijsbegeerte, Geologie, Geschiedenis der Natuurwetenschappen, etcetera).

In de vragenlijst van 1988 worden 25 academische studierichtingen onderscheiden. In een aantal gevallen worden studierichtingen in één cel bijeen gevoegd die volgens de Standaard Onderwijs Indeling (SOI) geen samenhang hebben. Zo wordt farmacie bij de medische wetenschappen ondergebracht. Geografie, bodemkunde en geologie vormen één categorie, evenals communicatie en informatica.

\section{- voor Functie/ Beroep:}

De zowel in 1983 als momenteel door het MPW gehanteerde indeling in 16 functie-groepen is tot stand gekomen naar aanleiding van de functieomschrijvingen van de respondenten van de enquête in 1978. De zo gekregen indeling is echter niet te herleiden tot de CBS-Beroepenclassificatie.

Door het MPW onderscheiden functies als 'Hoogleraar', 'ondernemer' of 'hoofd van een afdeling' zonder nadere beschrijving van respectievelijk het vakgebied of de aard van het bedrijf, komen als zodanig niet voor in de CBSBeroepenclassificatie. Wél onderscheidt de MPW-enquête een aparte rubriek van 16 Activiteiten zoals bijvoorbeeld 'Experimenteel onderzoek', 'onderwijs', 'beheer','administratieve activiteiten' etcetera. Een combinatie van 
deze informatie met de door de respondent opgegeven functie biedt misschien de mogelijkheid een nieuwe categorie beroep te creëren kunnen worden die wél overeenkomt met de CBS-Beroepenclassificatie. Het meest ideaal zou echter zijn als dezelfde open vragen gesteld zouden worden als in de Enquête Beroeps Bevolking van het CBS en vervolgens de codering zou plaatsvinden volgens de CBS-Beroepenclassificatie.

- Indeling voor Geografische spreiding van standplaats en delokatie van de betalende werkgever:

Eénderde van de Wageningse ingenieurs verblijft na het afstuderen voor korte of lange tijd in het buitenland. Om een beeld te krijgen van hun geografische spreiding is de wereld in een 12-tal regio's ingedeeld.

- Indeling voor concurrerende opleidingen:

In de vragenlijst is tevens de vraag opgenomen welke opleiding het beste aansluit op de functie van de respondent. In de toelichting op deze vraag wordt voorzien in 49 voorgecodeerde mogelijkheden van een concurrerende opleiding. Het gaat om 26 academische opleidingen, 9 HBO-richtingen en 10 MBO-richtingen.

- Indeling voor reden functieverandering:

In de Toelichting wordt voorzien in 18 voorgecodeerde redenen voor functieverandering (inclusief code 00 : niet van toepassing, geen vorige functie). Code 19 is voor de categorie 'Andere redenen'.

- Indeling voor wijze van functie-verwerving:

Hier wordt in 16 voorgecodeerde mogelijkheden voorzien.

- Indeling voor moeilijkheden tijdens sollicitatie:

Hier wordt in 12 voorgecodeerde keuzemogelijkheden voorzien.

- Belangrijkste reden tot afwijzing bij sollicitatie:

Hier kan uit 14 voorgecodeerde mogelijkheden worden gekozen.

Ook bij de drie laatstgenoemde categorieën vragen is voorzien in niet-inhet-rijtje-genoemde mogelijkheden. Bij deze vragen bestaat telkens de mogelijkheid om een antwoordcategorie 'anders' aan te geven waarbij tevens nadrukkelijk gevraagd werd om deze afwijkende situatie te beschrijven zodat in een volgende enquête deze situatie als keuzemogelijkheid kan worden opgenomen: een informatiebron voor de verdere instrument-ontwikkeling. 
BIJLAGE III: Definities en classificaties AGCAS (Groot-Brittannië)

I. Indeling van de Basisvragenlijst:

De standaardvragenlijst die in het Verenigd Koninkrijk wordt voorgelegd aan alle afgestudeerden uit het voorgaande academische jaar, bevat de volgende zes basisvragen over:

1. de 'primary classification'; (de eerste bestemming van afgestudeerden na hun studie)

2. indien werk: 'employer category';

3. en: 'type of work;

4. en: 'location of the employer';

5. allen: 'qualification obtained' (behaalde graad);

6. en: 'class of degree where appropriate' (jaar van afstuderen);

II. De daarbij gebruikte classificaties:

ad.1: Voor de PRIMARY CLASSIFICATION:

Hieronder wordt de bestemming verstaan op uiterlijk 31 december ná het academisch jaar waarin men afstudeerde. (In Engeland eindigt dat op 31 september). De mogelijkheden waaruit de respondenten kunnen kiezen zijn hiervoor onder het kopje 'primary classification' opgenomen. De volgende categorieën worden onderscheiden:

I. EMPLOYMENT OR FURTHER STUDY/ TRAINING

1.1 Employment;

1.2 Study/ training;

II . OTHER ARRANGEMENTS

2.1 Overseas students leaving the UK;

2.2 Not available;

II I. NO KNOWN ARRANGEMENTS

3.1 No employment/ study/ training;

3.2 No/insufficient information.

ad.2: Indeling voor de EMPLOYER CATEGORIE:

Hier worden drie hoofdgroepen van werkgevers onderscheiden, te weten: groep 100: 'public and general services, groep 200: 'manufacturing and allied industries and services' en groep 300: 'professional, commercial and allied services'. Daarnaast zijn er nog groepen voor 'self-employed' (groep 081) en 'Unknown' (groep 091). De laatste mag alleen gebruikt worden als de 'Type of work' bekend is. Deze drie hoofdgroepen bestaan uit 21 sub-groepen, zoals 110: International Organisations, 120: Central Government en 130: Local Government. Sommige van deze 21 sub-groepen zijn weer verder gedeeld in 94 'soorten' werkgevers. Zo bestaat Sub-Group 120, Central Government uit Civil Service (code 121) en Armed Forces (code 122).

Overigens gaat de algemene indeling vergezeld van een alfabetische lijst met een groot aantal namen van (grote) werkgevers met de daarbij behorende code. 
Dit om de universiteiten (respectievelijk de daarbijbehorende Careers Advisory Services) behulpzaam te zijn bij het coderen.

ad.3: Indeling voor TYPE OF WORK:

De classificatie voor 'Type of work' bestaat uit zes groepen plus een groep voor 'Unknown'. De zes groepen met bijbehorende codes zijn:

400 Management and supporting occupations;

500 Scientific, engineering, technological and environmental;

600 Education, welfare, health, security, protection;

700 Information and non-scintific research;

800 Creative/ entertainment;

900 Non-professional and non-management occupations;

091 Unknown.

Deze zes groepen zijn onderverdeeld in 29 sub-groepen zoals bijvoorbeeld sub-group 410: Administration, operational management. Deze 29 sub-groepen zijn weer onderverdeeld in 78 kleinere categorieën. Zo bestaat de hiervoorgenoemde sub-groep 410 uit zes kleinere categorieën: 411: General Administration; 412: Production Management; 413: Transport, Distribution Management; 414: Farming, Fishing; 415: Land Management; en 416: Hotel, Catering, Amenity Management.

ad.5: Universities Standard classification of Academic Subjects.

Deze classificatie is het resultaat van samenwerking tussen de UCCA: Universities Central Council on Admissions, de USR: Universities Statistical Records en de University Grants Committee.

De ontwikkelde classificatie sluit aan bij de door het Department of Education and Science (DES) ontwikkelde classificatie die aansluit bij ISCED. Deze is dan ook evenals de Standaard Onderwijs Indeling van het CBS bruikbaar voor álle niveaus en richtingen binnen het onderwijs.

De classificatie is gebaseerd op een onderscheid in 130 hoofdrichtingen van studie. Deze zijn geordend in 19 groepen rondom 10 onderwerpen. Zo bestaat er bijvoorbeeld de groep 'Humanities' die onder meer de richtingen Geschiedenis, Archeologie, Theologie en Filosofie bevat. Iedere groep wordt gekarakteriseerd door een letter. Iedere richting door een nummer. Zo heeft iedere hoofdrichting een unieke code die bestaat uit de groepsletter gevolgd door het richtingnummer. Zo valt Zoölogie (C3) onder de groep Biological Sciences (C).

Voor een uitgebreid wetenschapsterrein met een grote hoeveelheid studierichtingen zoals bijvoorbeeld Talen zijn meerdere groepen in gebruik. De groepen $Q, R$ en $T$ zijn alle voor talen. Zo heeft Duits code R2 en Chinees code T3.

Naast de 19 groepen is er nog een twintigste groep, groep $Y$, voor die studierichtingen die niet in één van de overige 19 groepen ondergebracht kunnen worden. Zo zal bijvoorbeeld een multidisciplinaire afstudeerrichting waarin drie of meer richtingen bij elkaar komen, tot groep $Y$ gerekend worden. 
Een volledige classificatie bestaat uit vier karakters. Zo kunnen combinaties van twee hoofdrichtingen worden samengesteld. Een niet-samengestelde studierichting, bijvoorbeeld Duits of Chinees, bestaat uit een letter en cijfer gevolgd door twee nullen. Maar een studierichting als 'Scandinavian Languages' (met code R7) kent weer verbijzonderingen, bijvoorbeeld Deens $(R 740)$ en Zweeds (R720).

Naast deze groepen en richtingen zijn de Major/minor combinations en de Balanced combinations van belang. Met de major/minor combinations kan het onderscheid tussen hoofd- en bijrichting worden aangegeven. Zo krijgt een afgestudeerde in Economics (L1) met Accountancy (N4) als bijvak de code L1N4: Economics with Accountancy.

Met de zogeheten balanced combinations wordt aangegeven dat de samenstellende richtingen in gelijke mate in de studie aanwezig waren. Zo zal een afgestudeerde in Economics and Accountancy de code LN14 of NL41 krijgen. (Maar niet LN41 want dat zou betekenen Social Policy and Business Studies). 
BIJLAGE IV: Publicatie-overzicht van geĩnventariseerde deelmarkt-studies

Voor de inventarisatie van de deelmarktstudies werd gebruik gemaakt van de volgende publicaties en informatiebronnen:

\section{LETTEREN:}

Doeksen, H.J. en Leo Jansen, Buiten verwachting?! , Beroepen van Neerlandici afgestudeerd te Utrecht in de jaren 1978-1985 en de arbeidsmarkt, RU Utrecht, 1986.

AGRARISCHE WETENSCHAPPEN (EN HUISHOUDKUNDE)

Stichting Maatschappelijke Plaats Wageningse Afgestudeerden NILI, Loopbaanenquête 1983, dee 1 I \& II, Wageningen, 1985.

\section{WIS- EN NATUURKUNDE}

Lingeman, E.W.A, De Nederlandse Natuurkundigen, Onderzoek naar werkgelegenheid. Nederlandse Natuurkundigen Vereniging, Commissie Werkgelegenheid voor Fysici, 1984.

Kwantes, P.M. en J.W. Engbers, Opleiding en bestemming van biofysici 19831984, Koninklijke Nederlandse Akademie van Wetenschappen, Commissie voor de Biochemie en de Biofysica, januari 1987.

Kwantes, P.M. en J.W. Engbers, Arbeidsmarkt voor biochemici 1984-1985, Koninklijke Nederlandse Akademie van Wetenschappen, Commissie voor de Biochemie en de Biofysica, december 1986.

Linde, drs. P. van der e.a., De vraag naar biologen, een onderzoek onder werkgevers, NIBI Arbeidsmarktonderzoek 1, Utrecht 1984.

Tichelaar, M., Biologen en Biologieleraren op de arbeidsmarkt, resultaten van een enquête onder afgestudeerden aan de universiteiten, NIBIArbeidsmarktonderzoek 4, Utrecht 1987.

De werkloze bioloog, Uitgave van de Werkgroep Werkloze Biologen, Utrecht, 1979.

TECHNISCHE WETENSCHAPPEN

\section{MEDISCHE OPLEIDINGEN}

Koninklijke Nederlandse Maatschappij voor Diergeneeskunde, Jaarboek 1987, p. 336-342. Gebaseerd op: ledenadministratie. 


\section{GEZONDHEIDSWETENSCHAPPEN}

Kramer, C. en M. L. Schreurs, Beroepsperspectief van gezondhe idswetenschappers, Verslag van een enquête onder afgestudeerde gezonheidswetenschappers' Rijksuniversiteit Limburg, Faculteit der Gezondheidswetenschappen, Maastricht, mei 1988.

\section{PHARMACIE}

Eekhoff, R.M.W., Farmaceutisch jaaroverzicht 1986 in cijfers, In: Pharmaceutisch Weekblad (122), 1987, p. 715-720.

\section{RECHTEN:}

Vinger aan de pols, Onderzoek naar de positie op de arbeidsmarkt van Rotterdamse juristen afgestudeerd in het jaar 1986, Erasmus Universiteit Rotterdam, Faculteit der Rechtsgeleerdheid, Bureau Onderwijszaken, april 1988.

Roos, N., vragenlijst voor een enquête onder afgestudeerde juristen afkomstig van de Rechtenfaculteiten van de RUG, de RUL en de RL.

ECONOMISCHE WETENSCHAPPEN En BEDRIJFSKUNDE (drs.):

Adressenbestand Stichting Landelijke Adreslijst Economisten, secretariaat mevr.Vroom-Vos, Bachlaan 72102 EG Heemskerk, tel. 023-281443

Adressenbestanden Verenigingen van afgestudeerde bedrijfskundigen

ECONOMETRIE, AKTUARIAAT En BEDRIJFSKUNDE (ir.):

Adreslijst Vereniging Afgestudeerde Econometristen Tilburg, secretariaat: Sint 010flaan 32A, 5037 ES Tilburg

Adreslijsten Verenigingen van afgestudeerde Bedrijfskundigen: secretariaten verbonden aan faculteiten/ Technische Universiteiten.

\section{SOCIAAL CULTURELE WETENSCHAPPEN}

Cremers, W.J.G. en Th. J. IJzerman, De beroepsperspectieven voor sociologen, (60) 1985, nr 1, Mens \& Maatschappij, p. 79-90.

Dijkstra, Carel en Joep Bannenberg, Er zijn teveel klinisch psychologen, In: De Psycholoog (11) 1986, p.178-182. 
Heide, Hugo P. de, Politicologen aan het werk, Een bespreking van de resultaten van een enquête onder afgestudeerde politicologen van de UvA. Subfaculteit der Algemene Politieke en Sociale Wetenschappen, zomer ' 82.

Holtzer, F.H.J.M., Is er toekomst voor psychologen?, In: De Psycholoog (14) 1984, no. 6, p. 257-266.

Kerkhof, A.J.F.M. en G.I. Engels, Enkele gegevens over de werksituatie van psychologen afgestudeerd tussen september 1983 en september 1986 aan de Rijksuniversiteit Leiden, met als specialisatie klinische psychologie, Leiden, oktober 1986.

Leeuw, E.D. de, en J.J. Hox, Meningen en werksituatie van pedagogen, afgestudeerd aan de Universiteit van Amsterdam in het studiejaar 19851986, In: Nederlands Tijdschrift voor Opvoeding, Vorming en Onderwijs, Vol.4, no.1, 1988.

Rodenhuis, $W_{0}:$ Jonge politicologen aan het woord over opleiding en werkkring, Acta Politica, 1987, p. 327-346.

Schaufeli, Wilmar, Werk en werkloosheid onder klinische psychologen 19831986, Verslag van een enquête gehouden onder afgestudeerde klinische psychologen van de RU.Groningen, Groningen, augustus 1987.

Voor hoofdstuk 4 werd gebruik gemakt van:

Telefonische- en schriftelijk verkregen informatie van:

- Universities Statistical Record

P.0. box 130

Cheltenham, Gios, GL50 1JW

U.K.

(Telephone: (0242)222444)

- The Graduate Employment Service

Central Services Unit

Crawford House, Precinct Centre

Manchester M13 9EP

U.K.

(Telephone: (061)273 4233)

Tevens:

Johnes, Geraint; Jim Taylor and Glenys Ferguson: The Employability of New Graduates: A Study of Differences Between UK Universities, In: Applied Economics, 1987, Vol.19, p.695-710 
